Portland State University

PDXScholar

$1-1-2012$

\title{
William Marshal, 2nd Earl of Pembroke, and the Commissioning of the History of William Marshal
}

Chloe Faith Massarello

Portland State University

Follow this and additional works at: https://pdxscholar.library.pdx.edu/open_access_etds Let us know how access to this document benefits you.

\section{Recommended Citation}

Massarello, Chloe Faith, "William Marshal, 2nd Earl of Pembroke, and the Commissioning of the History of William Marshal" (2012). Dissertations and Theses. Paper 330.

https://doi.org/10.15760/etd.330

This Thesis is brought to you for free and open access. It has been accepted for inclusion in Dissertations and Theses by an authorized administrator of PDXScholar. Please contact us if we can make this document more accessible: pdxscholar@pdx.edu. 
William Marshal, $2^{\text {nd }}$ Earl of Pembroke, and the Commissioning of the History of William Marshal

by

Chloe Faith Marie Massarello

A thesis submitted in partial fulfillment of the requirements for the degree of

\author{
Master of Arts \\ in \\ History
}

\title{
Thesis Committee: \\ John Ott, Chair \\ Caroline Litzenberger \\ Thomas Luckett \\ Christine Rose
}

Portland State University

(C)2012 


\begin{abstract}
In the mid-1220s, William Marshal, second earl of Pembroke, commissioned the History of William Marshal, a verse history which recounts the life of his father, the first earl of Pembroke. The History has been utilized as a source of information about its titular subject by modern historians, but none have examined the causes behind its commissioning and the significance of the document within the context of the second earl's political career in depth. This thesis seeks to increase understanding of the History by placing it within this context and examining the second earl's influence on its contents.

Primary sources, including contemporary letters and court records contained within the Curia Regis Rolls, help reconstruct the political career of the second earl and reveal the reasons why he may have found it expedient to commission the History. An analysis of the History itself indicates that the document reflects the second earl's concerns.

The introduction and first chapter of this thesis provide historiographical background for the History, both within its contemporary setting and as a type of work analyzed by modern historians. They indicate the importance of understanding the political and social function of the History and argue that the modern label of biography should not be applied to it. In the second chapter, primary sources and detailed studies of the minority and reign of Henry III are utilized to illustrate the second earl's political career and his conflicts with fellow barons and the crown over property and his unconventional marriage into the royal family. The third chapter offers an interpretation
\end{abstract}


of the History with reference to the earl's career. This thesis concludes that the second earl commissioned the History in response to the objections raised to his marriage. 


\section{Acknowledgments}

First and foremost, I would like to extend my love and thanks to my parents, who have supported me whole-heartedly throughout my academic journey. They may have wanted a scientist and got a historian, but they remained unflinching in their determination to let me be me. Next, I would like to express my appreciation for the guidance and mentoring that I received from my two advisors, Dr. John Ott and Dr. Caroline Litzenberger. They helped me grow as a historian, and without them I would likely still be trying to decipher some arcane Latin document written in an illegible hand. Finally, I thank the History Department, the Pacific Historical Review, and the Religious Studies Department for the wonderful opportunities that I was given as a graduate assistant, and the many friends that I gained as a student for their warm support. 
Table of Contents

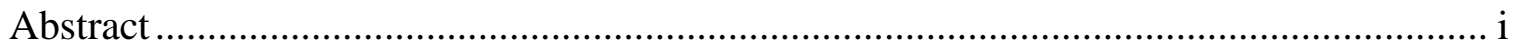

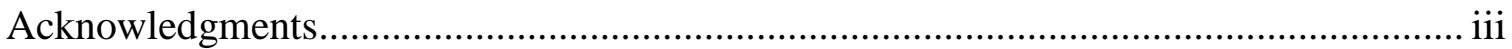

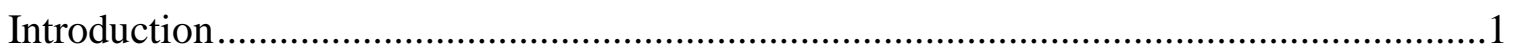

Chapter One

The History and its Historiographical Context ........................................................ 18

Chapter Two

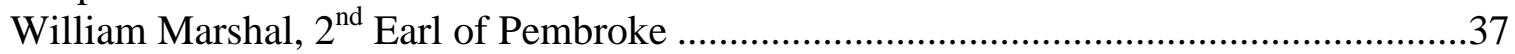

Chapter Three

The History and the Earl ...............................................................................65

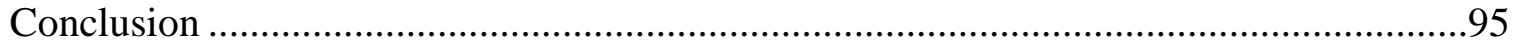

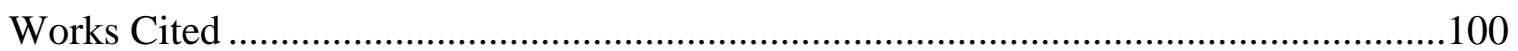


Introduction

In 1226 the poet John penned the closing lines of an epic work of history in verse. A sole manuscript copy housed in the collections of the Pierpont Morgan Library in New York testifies to the labor of the poet and the life of one of the most powerful noblemen of the Angevin empire. ${ }^{1}$ From childhood to death across the reigns of six kings, John traces the tableaux of William Marshal's (c. 1147-1219) story as he was raised from the position of a younger son of a minor baron to the regency of England. Rather than a chronicle or other broad-ranging history, John produced a work tightly focused on its protagonist and his political career. There are few scenes in which Marshal is not present, from the twelfth-century tournament circuit to the critical battles of the First Barons' War (1215-1217). The character of the Marshal dominates the narrative.

Modern historians have not neglected the History of William Marshal. Over the past century, six biographies have been written of Marshal that use the poet John's work extensively, and sometimes nearly exclusively. ${ }^{2}$ The History has also been utilized to study other aspects of the medieval world, such as the concept of chivalry, the tournament, and romance literature. Missing from the vast majority of the material written concerning the Marshal and his world, however, is the history of the History itself. Only recently have historians made an effort to explore the impetus behind its

\footnotetext{
${ }^{1}$ The fact that only one copy of the manuscript survives is not an uncommon plight for Plantagenet-era historical works. See Nicholas Vincent, "The Strange Case of the Missing Biographies: The Lives of the Plantagenet Kings of England, 1154-1272," in Writing Medieval Biography, 750-1250: Essays in Honour of Professor Frank Barlow, ed. David Bates, Julia Crick, and Sarah Hamilton (Woodbridge, Suffolk: Boydell Press, 2006), 251.

${ }^{2}$ Although it is the most recent, the sixth biography does not engage the historiography or provide any substantial analysis. See Catherine Armstrong, William Marshal, Earl of Pembroke (Kennesaw, Ga.: Seneschal Press, 2007).
} 
creation and what it may have meant to the man who commissioned it. No historian has yet set the History within its contemporary context or undertaken a sustained exploration of the purpose it held within the Marshal family. Although William Marshal, $1^{\text {st }}$ Earl of Pembroke, is indisputably the subject of the work, the History was begun after his death. It was not a work meant to gratify and please a living subject, but a work of family history meant to benefit the subject's living descendents, and mainly Marshal's eldest son, William Marshal, $2^{\text {nd }}$ Earl of Pembroke (1190-1231). In this sense, William the younger is the true subject of the History. In light of the existing scholarship on the History and its subject, this thesis will provide a context for the document that illustrates its role in the career of William Marshal the younger. The History reflects young William's interests and was a response to the political conflicts of his career, as well as to the marriage alliance between himself and the royal house of England that came to fruition in 1224. William's new social status and the attacks that his position engendered gave rise to the History, a unique and highly focused justification for the power of the Marshal family, and a defense of its claims and moral rectitude.

The position of prominence that the second earl of Pembroke inhabited in the 1220s was owed entirely to his politically astute father and his years of service to the Plantagenet monarchs. Nothing in the family's origins could have predicted the amount of success achieved by the elder William Marshal. He was the fourth son of John Marshal, a minor English baron. The family line cannot be traced beyond John more than one generation. ${ }^{3}$ William was sent to live in the household of his cousin, William de

\footnotetext{
${ }^{3}$ See David Crouch, William Marshal: Knighthood, War and Chivalry, 1147-1219, 2d ed. (London: Longman, 2002), 13. All citations of Crouch's biography of Marshal will refer to this edition. The first
} 
Tancarville, and undergo training to become a knight in France. ${ }^{4}$ During his years on the Continent he became known for his skill in the tournament, attracting the attention of King Henry II of England (r. 1154-1189), who appointed him to the household of his eldest son, Henry the Young King. Upon the younger Henry's death in 1183, William entered the service of Henry II directly. He was promised Isabel de Clare in marriage for his service, and, although Henry died before the marriage could take place, Richard I (r. 1189-1199) confirmed the gift upon his accession to the kingship. The marriage made William lord of Striguil in Wales and Longueville in Normandy and marked his first major land acquisition. ${ }^{5}$ Later King John (r. 1199-1216) raised Marshal to the earldom of Pembroke, making him one of the most powerful members of the English nobility. ${ }^{6}$ Marshal fought for the king during the First Barons' War and spent his last years as regent of England and guardian of the child-king, Henry III (r. 1216-1272).

In 1190, William and Isabel had their first son, also named William. Father and son initially fought on opposing sides during the First Barons' War, with William the younger supporting the invasion led by the French King Philip Augustus's (r. 1180-1223) son Louis. After King John's death, the younger William returned to the service of the English king, now Henry III, and entered into his inheritance as second earl of Pembroke upon his father's death. In 1224 William married Henry III's sister Eleanor, further strengthening the close ties between his family and the royal house. Upon his death in

edition was published under a different title. See David Crouch, William Marshal: Court, Career, and Chivalry in the Angevin Empire, 1147-1219 (London: Longman, 1990).

${ }^{4}$ The exact relationship between the Marshals and Tancarvilles is not known with complete certainty. See ibid., 23.

${ }^{5}$ Ibid., 67-68.

${ }^{6}$ Ibid., 86-87. 
1231, his brother Richard inherited his lands and titles, since William's marriage had produced no heirs.

Although the precise date is unknown, at some point after his father's death in 1219, William decided to commission a work dedicated to telling his father's story. The result, the History of William Marshal, is a 19,215-line poem written in French and authored by an otherwise unknown poet identified only by his first name. ${ }^{7}$ It chronicles the career of William Marshal, beginning with his childhood and the exploits of his father John Marshal in the service of Empress Matilda. The first half of the poem details William's rising star on the tournament circuit in France and his appointment to the Young King's household and subsequent service to King Henry II. The second half

\footnotetext{
${ }^{7}$ The authorship of the History has been debated among historians. Although most have agreed that the poet John's identity is a mystery, it has been asserted that John the poet was actually John of Earley, the elder Marshal's squire. In the epilogue of the History, the poet names himself and Earley in close proximity, resulting in ambiguity. Earley was very involved with the History, both as a source of information and, apparently, as a source of funds. The poet wrote that John of Earley "put his heart and soul and wealth / into the enterprise, as is so abundantly obvious / that nobody should have any doubt on that score. / True affection is revealed in all good deeds done, / and that, I can tell you, is no falsehood, / for John, who wrote this book, / has well shown that such is the case." These lines are preceded by an acknowledgment of William's monetary support ("no amount of expense would have deterred him / from seeing it executed") and followed by a blessing on those involved in the work, suggesting that the affection referenced by the poet is that of William and Earley, and that the commissioning of the work reveals it. See History of William Marshal, ed. A. J. Holden (London: Anglo-Norman Text Society, 2004), 2:461-463. Evelyn Mullally has pointed to the simplicity of the verse, the claims of the author to have been an eyewitness to certain events, and the unclear reference to young Marshal's funding, among other things, as evidence that Earley was in fact the author. See Mullally, "Did John of Earley Write the Histoire de Guillaume le Maréchal?" in The Court Reconvenes: Courtly Literature Across the Disciplines, ed. Barbara Altmann and Carleton Carroll (Cambridge: D. S. Brewer, 2003), 256-264. Although a former squire helping to fund such a major work may appear odd, it can be partially explained by the fact that young Marshal entered upon an inheritance financially drained from years of war. He struggled financially early on, and the History recounts that he was in fact advised to have the work commissioned. It is possible that Earley had to supply any initial funds. For Marshal's financial situation, see William Marshal, Earl of Pembroke, to Henry III (no. LVIII) in Royal and Other Historical Letters Illustrative of the Reign of Henry III, ed. Walter Waddington Shirley (London: Longman, Green, Longman, and Roberts, 1862), 70. The identification of Earley as the author has been rejected by the compilers of the most recent edition of the History. As A. J. Holden has explained, "the author was a professional writer, who lived, as he tells us, by his pen...not a statement which could be attributed with any degree of likelihood to a person of John of Earley's high standing, whose military and administrative activities would, in any case, hardly have allowed him the leisure necessary for the composition of a poem of nearly 20000 lines." See Holden, "Textual Introduction," in History of William Marshal, 3:4.
} 
largely records Marshal's troubled relationship with King John, the armed struggles between John and his barons, and Marshal's regency, coming to a natural conclusion at the death of the earl. As a historian, the poet John was able to draw from the memories of the living members of the elder Marshal's household, including his children and his squire, John of Earley, and he makes reference to written records. The poet was a reflective historian who often comments on the quality of his sources throughout the text, especially when he has been given conflicting information. He also drew from the tradition of romance literature, enriching the text with elements found in the works of Chrétien de Troyes.

The beginning of any story sets the tone for what follows, and in the case of a narrative like the History of William Marshal, sometimes consciously provides the reader with an interpretive framework for the rest of the document. Although the poet John, like any historian, had to make choices about what information to include in his story and how to represent that information, he indicates to his readers why there was a need for his work. John opens the History with the following lines:

A writer with a worthy subject in mind should so arrange matters that, from the fine start he gives his story, it is brought to a fitting [conclusion], and [he should write] in such a way that his words have the ring of common sense, with nothing in them to invite censure; for there are those who, though having little understanding, make a habit of going on the attack, bent on denying that what is good is so. And where does this habit of theirs come from? From envy. A man who, out of deep-seated bitterness, cannot hold his tongue, will not be pleased, either, with good things, however great. 
However, so help me God, the main point is that my tale is of the worthiest man who ever lived in our times. ${ }^{8}$

John's words are not overly specific. It is clear that someone or something is under assault, and, in light of the modern scholarly consensus that the senior Marshal's reputation suffered after his death, it is easy to conclude that the poet is referring to it in these lines. However, the poet's reference to envy and his use of the present tense indicate that the attack is directed at a living object. There was no need to envy the dead Marshal, or the dead Marshal's reputation, but there was reason to envy his son. Since the son owed his powerful position and opportunities to his father, attacking the father was an effective means of attacking the son.

An examination of available records pertaining to the second earl of Pembroke's political life in the decade following his father's death in 1219 does reveal that he had become something of a lightning rod for conflict. The tensions of the early years of the reign of Henry III resulted in shifting alliances and dangerous situations for the king and his barons. Records pertaining to cases preserved in the Curia Regis Rolls reveal that Marshal was involved in difficult and bitter property battles with fellow barons. Contemporary letters testify to struggles over the control of important royal castles and Marshal's controversial alliance with royal justiciar Hubert de Burgh and the king. Taken together, these sources help reconstruct a picture of Marshal's political reality and circumstances during the 1220 s that can greatly increase our understanding of the History and young Marshal himself.

\footnotetext{
${ }^{8}$ History of William Marshal, 1:3.
} 
As a source, the History has been easily accessible to historians for over a century. The first edited version of the History was produced by Paul Meyer in the 1890s. His introduction to the text offers a relatively short analysis of the work that places it in a literary context, but not a detailed historical one. Meyer's most valuable contribution for the purpose of this thesis is his work on the History's date of composition. Meyer combed through the text for references that could be used to assign a date to the work, since the History itself does not disclose when John the poet received the commission, began his writing, or ended it. Ultimately, Meyer could not assign a specific date to the inception of the History or determine how many years the work had taken, but concluded that it had been completed in $1226 .{ }^{9}$ He based his conclusion on several clues within the text, the majority of which involve individuals being discussed as living or deceased. Subsequent historians have accepted Meyer's dating, and the premise that the History was completed in 1226 is also accepted in this thesis.

As to the purpose of the History, Meyer asserted that it had been created to preserve the memory of William Marshal and that it should be categorized as a chanson de geste, along with poems like Girart de Rousillon and Raoul de Cambrai. ${ }^{10}$ The value of the History, according to Meyer, is its unique ability to paint convincing portraits of Marshal and his leading contemporaries. Unlike the aggrandized or otherwise exaggerated accounts prevalent during Marshal's time, in the History, "tout est réel."11

\footnotetext{
${ }^{9}$ Paul Meyer, L'Histoire de Guillaume le Maréchal, Comte de Striguil et de Pembroke, regent de Angleterre de 1216 à 1219: poème français (Paris: Renouard, 1891), 3:ix. Meyer was far less definite about the year the work was begun. He postulated that, if the idea for the History had been born at the time of William Marshal's death, it probably would have taken a significant amount of time for all of the required materials to be gathered and the writing to begin. See ibid., vii.

${ }^{10}$ Ibid., i.

${ }^{11}$ Ibid., ci. That is, "all is real."
} 
While Meyer did acknowledge that the History suffers from chronological errors and omissions, he judged that the poet John, although favoring Marshal, was largely impartial in the treatment of his subject, and strove to reproduce the information in his sources accurately. ${ }^{12}$ Only recently have historians begun to look more closely at the History.

The first modern biography of William Marshal was written by Thomas Leckie Jarman in 1930. It is a short narrative of Marshal's life that utilizes the History along with other primary sources (contemporary chronicles and government documents) and secondary sources for context. Jarman did not engage in any source criticism or describe his methodology in selecting particular sources and privileging particular accounts over others. This general lack of analysis is also found in the first major biography of the Marshal, written by Sidney Painter and published only three years after Jarman's book. ${ }^{13}$ Painter's biography utilizes the History along with numerous other primary sources to present a detailed account of Marshal's life, but he does not critique the History or comment on the work as a source. ${ }^{14}$

Jessie Crosland made the first comment concerning the purpose and reliability of the History of any of the Marshal biographers. Unlike Painter's detailed rendering of Marshal's life and times, Crosland's work is a reconstruction of the original History in narrative form. It is not a translation, but the History is the only source that Crosland employed, and he was confident of its virtue as a first-class historical source. While "the

\footnotetext{
${ }^{12}$ Ibid., ciii and cvii.

${ }^{13}$ See Thomas Leckie Jarman, William Marshal, First Earl of Pembroke and Regent of England (12161219) (Oxford: B. Blackwell, 1930); and Sidney Painter, William Marshal: Knight-Errant, Baron, and Regent of England (Baltimore: Johns Hopkins Press, 1933).

${ }^{14}$ One important exception to Painter's reticence occurs when he is confronted with conflicting narrative accounts of Marshal's dealings with Louis of France. He noted that the History may have been addressing rumors of disloyalty that Matthew Paris recorded years later.
} 
chronology of events may be somewhat dim and their importance misjudged," Crosland held that the History "is not full of surmises and assumptions like so many modern historical biographies." 15 The purpose of the work was, simply, to honor the Marshal's memory. ${ }^{16}$

In her magisterial study of medieval English historiography published in 1974, Antonia Gransden characterized the History as a work meant to entertain and gratify the members of the Marshal family. She averred that "the contents of the History were mainly determined by two factors: the chivalric ideal and love of the Marshal and his family. Both factors sometimes led to a biased historical viewpoint, but usually the author's sense of reality predominates. He depicts the Marshal as the perfect knight, a portrait which, as far as is known, corresponded with reality." ${ }^{17}$ Gransden acknowledged young Marshal's patronage of the work but did not explore how it may have affected the content of the History in her discussion.

More sustained interest in the purpose of the History and analysis of its contents entered the scholarship with Georges Duby's biography, William Marshal: The Flower of Chivalry. Duby's stated purpose was not to reconstruct Marshal's life and times like Painter had done, but to gain an understanding of the thought world of a medieval baron, as represented by Marshal. ${ }^{18}$ In light of this, the first reason that Duby proposed for the commissioning of the History was the maintenance of the family reputation through the

\footnotetext{
${ }^{15}$ Jessie Crosland, William Marshal: The Last Great Feudal Baron (London: Peter Owen, 1962), 9, 10.

${ }^{16}$ Ibid., 8.

${ }^{17}$ Antonia Gransden, Historical Writing in England c. 550 to c. 1307 (Ithaca, New York: Cornell University Press, 1974), 1:322, 346, 349.

${ }^{18}$ Georges Duby, William Marshal: The Flower of Chivalry, trans. Richard Howard (1984; trans., New York: Pantheon Books, 1985), 38.
} 
preservation of its most illustrious member's memory. As Duby observed, “the song would testify, then, to the pride attached to an extraordinary success." 19 Secondly, Duby recognized the History's tendency to magnify its subject's good qualities and ignore the less than ideal. Literature of this kind was meant to "defend the interests of the house by exonerating those members whose conduct was under attack," as was the elder Marshal's, posthumously. ${ }^{20}$ But this is where Duby stopped. He did not elaborate on the role that the poet John's work played in the lives of Marshal's living family or link his ideas to actual events. $^{21}$

The most recent historian to produce a biography of the Marshal, David Crouch, has dedicated a much greater amount of attention to the intent behind the History and the contents of the work itself. In his biography of Marshal, Crouch has explained that "the younger Marshal knew that many people believed that his dead father had been a man of compromised loyalties, far too friendly with the Capetian kings of France. The biography would set the record straight, once and for all, and he would discharge the debt to his father's memory." 22 In respect to this purpose, the History "gives many details and insights into what the Marshal did and why he did it. It is also concerned to give a (highly

\footnotetext{
${ }^{19}$ Ibid., 29.

${ }^{20}$ Ibid., 37.

${ }^{21} \mathrm{He}$ does assert that the History tells us that it was commissioned by the younger William Marshal specifically for his siblings, and that "he owed them this gift as their elder and as the heir." Ibid., 29. However, nowhere in the new translation of the History does it say that William commissioned it for his siblings or that there was any obligation involved, and it is my belief that the original French does not sustain such an interpretation. The relevant lines are 19,201-19,205. The modern translation reads, "When the family line, both brothers and sisters, / hear this tale, they will have it very much to heart / that their brother, the worthy Marshal / William, should have commissioned a life of their father / such as this. The French reads, "Quant li lignages, frerre e suers / Orront ce, molt lor iert as cuers, / Que li buens Mareschal lor frere, / Willeaumes a fet de lor pere / Feire tel uevre cum cestui." The text goes on to wish them pleasure in hearing about their ancestor. These lines are the only ones in the incipit or explicit that refer to the younger Marshal's siblings. See History of William Marshal, 2:463.

${ }^{22}$ Crouch, William Marshal, 2.
} 
favourable) verdict on his life, and justify his political decisions and actions." ${ }^{23}$ Crouch's own verdict that the elder Marshal "hardly deserves complete absolution; there remains too much that was ambiguous in his political career for that," could apply to nearly any baron of any social and political milieu during the Middle Ages. ${ }^{24}$ Marshal's contemporaries and members of succeeding generations may not have idolized him, as Crouch notes, but this hardly explains why the young Marshal needed to produce an account of his father's life that was dedicated to giving it a coat of whitewash. Most barons survived without the whitewash, and a dead one certainly did not require it. Crouch recounts an anecdote from chronicler Matthew Paris in which "Henry III in later days peevishly berated the Marshal's son, Walter, for what he was pleased to call the old Marshal's treachery" in order to illustrate the need for the defense of Marshal's reputation. $^{25}$ The missing corollary is that memory of the elder Marshal was being resurrected and directed at one of his sons. In the anecdote, the son and his relationship with the king are affected by the memory of his dead father. In this sense, a posthumous defense is best understood as being undertaken for the sake of the Marshal's children. In addition to his observations about the History's relationship to the deceased Marshal's endangered reputation, Crouch has observed that it bears the marks of contemporary romantic and epic fiction. Marshal shares his title of "the best knight in all the world" with the mythical hero Guy of Warwick, for example. The History also contains more substantial, original fictional content, as opposed to embellishment borrowed from popular stories. Crouch points out that the account of the deaths of

\footnotetext{
${ }^{23}$ Ibid., 4.

${ }^{24}$ Ibid., 135.

${ }^{25}$ Ibid.
} 
Marshal's two brothers is completely fabricated, for instance, but is quick to reassure historians that enough independent evidence exists from the time of Marshal's life to identify inaccuracies, fabrications, and omissions with relative ease. ${ }^{26}$

A few years after the publication of the first edition of Crouch's biography, Elisabeth Gaucher summed up the purpose of secular medieval biographical works in her published doctoral dissertation. Gaucher asserted that "les auteurs des biographies travaillent à extraire du passé les arguments susceptibles de justifier le present." ${ }^{27}$ Despite this observation, Gaucher did not explore the concept in relation to the History. She categorized the History as a work meant to perpetuate the memory of a family member or enhance the prestige of a family, but did not discuss how it was meant to serve the specific interests of the commissioner of the work. ${ }^{28}$

A new edition and translation of the History was effected in 2002 and 2004 by Anthony J. Holden and Stewart Gregory. David Crouch provided historical context. In the multi-part introduction to the text, Holden described the poem as "an act of filial piety" meant to celebrate the life of the elder Marshal, and quite possibly defend the Marshal's suffering posthumous reputation. ${ }^{29}$ Crouch reiterated these ideas in his section of the introduction, asking the all-important question in regard to the author's intention, "are there other, less obvious, preoccupations stemming from political concerns in the 1220s of which we know nothing?"30 More recently, Crouch has published two articles in

\footnotetext{
${ }^{26}$ Ibid., 10-11.

${ }^{27}$ Elisabeth Gaucher, La biographie chevaleresque: Typologie d'un genre, XIIIe-XVe siècle (Paris: H. Champion, 1994), 568. "The authors of biographies worked to extract from the past arguments that were likely to justify the present."

${ }^{28}$ Ibid., 243.

${ }^{29}$ Holden, "Textual Introduction," 4, 7.

${ }^{30}$ Crouch, "Historical Introduction," in History of William Marshal, 3:39.
} 
which he has begun to address his own question. Writing in 2006, Crouch returned to the traditional idea of a posthumous defense but then moved on to point out that in the case of the poet John's discussion of the Marshal family's possession of Caerleon in Wales, the struggle that the elder Marshal had undergone to possess it was being echoed as John wrote by the younger William's battle in court over the same property. In Crouch's words, this "can be no coincidence." ${ }^{31}$ A year later Crouch produced an essay titled "Biography as Propaganda in the 'History of William Marshal." Some of this article borrows directly from his earlier publication, but it is the first example of the claim being made that the poet John was "employed consciously as a propagandist. ${ }^{, 32}$ Here the focus has finally shifted to the younger William and his agency as his father's heir.

Acknowledging once again that the History was likely an act of dutiful commemoration and perhaps arose out of genuine grief, Crouch exhibited a marked shift in thinking, commenting that "the cause that is most relevant and most obvious is political."

Previously, any claim of the political role of the History rested with the senior Marshal. Although it was asserted that his reputation was in need of defense, its effect on his son was never discussed. Crouch admits that there was a vital connection between the deceased father's reputation and his son's experiences. His observation that "we are...hearing the younger William Marshal's protests against his father's posthumous detractors" is one important part of the role of the History. ${ }^{34}$ However, after making this

\footnotetext{
${ }^{31}$ David Crouch, "Writing a Biography in the Thirteenth Century: The Construction and Composition of the 'History of William Marshal,"' in Writing Medieval Biography, 750-1250, 225.

${ }^{32}$ In Convaincre et persuader: communication et propagande aux XII et XIII siècle, ed. Martin Aurell (Poitiers: Université de Poitiers, 2007), 503.

${ }^{33}$ Ibid., 505.

${ }^{34}$ Ibid., 506.
} 
observation, Crouch enters into a lengthy discussion of the reasons why the senior Marshal's reputation was suspect. He gives several reasons, but their relation to the younger William is not even alluded to, except in the case of Caerleon, as previously discussed. Crouch makes the wide claim that "the commissioning of the History was one aspect of the earl's need to put his affairs in order before he departed to Ireland for an indeterminate period." ${ }^{35}$ However, Caerleon is the sole specific example of why "the Marshal biography was contemporary propaganda, as much as a genuine attempt to tell the life of William Marshal, earl of Pembroke" that Crouch gives. ${ }^{36}$ The reader is left to determine just how the son was affected by the "difficult legacy of mistakes and misjudgements" that his father had bequeathed to him. ${ }^{37}$ Crouch's points are valid, but ultimately he does not detach himself from the time of William Marshal senior in order to examine the History within the context of the time of the younger Marshal.

Another significant and misleading characterization of the work is the label of biography given to it by Crouch and other historians. Within the historiographical traditions of twelfth- and thirteenth-century England and France, the History does stand out as a text relatively unique in form. Most works are not as tightly focused on a single, secular individual as the History. However, while the period produced many works that could be described as biographical (within limits) or that contain biographical material, the genre of biography itself is a modern construct. Crouch has asserted that the act of writing a biography was "remarkable," for

\footnotetext{
${ }^{35}$ Ibid., 505.

${ }^{36}$ Ibid., 511.

${ }^{37}$ Ibid.
} 
there were few works written in the Middle Ages which might be called biographies. Studies written by medieval people about their kings generally tell us not so much about their lives, but their times. They give us little or no insight into their subject's early years, motives and inner life, as a biography should. Quite a number of bishops, abbots and monks were the subjects of Latin lives (vitae), but few are truly biographical. Most are 'hagiographies': that is, studies of the lives of saints. They were written to justify their subjects' saintly status and as devotional texts, not as biographies. ${ }^{38}$

In Crouch's view, then, the History "is a true biography, because it follows its subject from cradle to grave, and gives many details and insights into what the Marshal did and why he did it. ${ }^{39}$ However, while Crouch readily admits that the History is determined to depict Marshal in a highly favorable light and justify his actions, his use of the term biography at least partially disguises the constructed nature of the text.

The goals of the History, as recognized by Crouch and others, are not so very different from those of hagiographical works, as described by Crouch in the preceding block quote. Hagiographies were intended to make a strong case for the saintliness of their subjects, just as the History is determined to depict Marshal as an idealized, albeit lay, figure. Other historians have recognized the inadequacy of modern genre categories when applied to medieval writings. Felice Lifshitz has written that it is not "enough to say that, for centuries on end, there was much 'cross-over' or 'bleeding' or 'blurring' among genres; at a certain point, constant 'cross-over' must be taken as an indication that the categories themselves are hopelessly inadequate. ${ }^{40}$ For this reason, along with the substantially more pervasive and pressing issues of patronage, the History defies easy

\footnotetext{
${ }^{38}$ Crouch, William Marshal, 3-4.

${ }^{39}$ Ibid., 4.

${ }^{40}$ Felice Lifshitz, "Beyond Positivism and Genre: 'Hagiographical' Texts as Historical Narrative," Viator 25 (1994): 102.
} 
categorization as a biography and the modern expectations of a work of that genre. The History was a living document that was intended to interact with contemporary concerns, and in order to utilize it to the fullest as a source, it needs to be examined from the perspective of the second earl of Pembroke, rather than continue to be used almost exclusively as a source of information about his father.

It is not surprising that the historians who have utilized the History have dedicated their attention overwhelmingly to the elder William. The History does of course contain substantial, verifiable information about him. Young William is largely a silent figure who appears sparingly in the text of the History. His most lengthy appearance is during his father's extended death scene. Regardless of his absence, however, his father's modern biographers acknowledge his role yet fail to pursue it and its influence on the History. The compelling portrait of the elder Marshal that unfolds within its pages has proven irresistible. In light of this, the first chapter of this thesis provides historiographical context for the History and discusses both the problems inherent in regarding the work as a biography and the importance of examining the purposes of medieval historical texts. Utilizing primary sources, including contemporary letters and court records, and the intricately detailed histories of the early years of Henry III's reign produced by David Carpenter, Kate Norgate, and others, the second chapter of this thesis provides an account of young William Marshal's political career with historical context. It discusses the historical reasons why the second earl may have found it expedient to commission the History. Lastly, the third chapter examines the History itself to find the 
interpretive influence of the earl on the representation of his father and the events of his life. 


\section{Chapter One:}

The History and its Historiographical Context

The History contains many elements of a reliable historical account. John the poet reflects on his sources, whether written or oral, and historians like David Crouch are able to confirm the historicity of much of what the History describes. The interpretations of characters and events expressed within the History and the omissions from the narrative reveal that it was not solely intended as a history of Marshal's life, and was certainly never intended to be comprehensive. Historical and romantic elements are combined within the pages of the History to create the desired image of Marshal, his deeds, and his family in a manner that defies the easy categorization of the work as a biography. Modern historians have long recognized the multi-faceted and varied nature of medieval historiography and have spent countless pages examining the impetus behind the creation of individual works and certain types of works. A common thread running through these examinations is the need to understand why a work was commissioned and how its parts contribute to the fulfillment of its purpose. In the case of the History, the purpose is best encapsulated by the description of the work as a living document meant to influence and shape the view of the past and present in relation to its subject and the view to be held in the future.

A. J. Holden, one of the compilers of the recent edition of the History of William Marshal, has characterized it as the "earliest surviving biography in any European vernacular." 41 It is a unique text, he claims, and one that is substantially different from

\footnotetext{
${ }^{41}$ Holden, "Textual Introduction," 3.
} 
contemporary works, despite its many borrowings from both romance and the

conventions of historical writing more broadly. He has written that the History:

Can be assimilated neither to the hero-centric courtly romances nor to the Latin-based dynastic histories of Gaimar, Wace and Benoît, nor to the vernacular saints' lives, although it partakes of the characteristics of all of them. It is apparent that, for the author, the biographical purpose of his composition is paramount, and the function of the political, diplomatic and military events which he relates, often in considerable detail, is tangental [sic] to his main preoccupation: the enhancement of the hero's image and the enumeration of his exploits. ${ }^{42}$

Regardless of the unique attributes of the History, the classification of the work as a biography is only suggestive to modern readers of what they might expect from the text in terms of content, and potentially organization. No such classification is contemporary to the History, as medieval historians and writers did not share modern notions of genre or even of what constitutes history. ${ }^{43}$ As Holden points out, the purpose behind the History was the driving force which determined the form that the work took. Whereas he claims that the history of events woven into the text is tangential to that purpose, the events largely serve to affirm and illustrate the desired image of Marshal and the purpose of the work.

\footnotetext{
${ }^{42}$ Ibid., 6.

${ }^{43}$ For instance, in her comparative study of six twelfth-century historians, including William of Malmesbury, Geoffrey of Monmouth, and Gaimar, Jean Blacker asserted that "it is clear that these six historians did not share a monolithic view of historical writing...Various claims of truth are made by the historians, whose views on historical writing possess very few common threads, save the assumption that what they were producing was factual." See The Faces of Time: Portrayal of the Past in Old French and Latin Historical Narrative of the Anglo-Norman Regnum (Austin: University of Texas Press, 1994), 52. In terms of genre, Monika Otter has noted that history was included under the umbrella of rhetoric, along with poetry and fictional writings. She has explained that "genre distinctions were certainly permeable, probably more so than they are now. Saints' lives (supposedly the biographies of actual persons) may resemble secular romances and vice versa; romances or epics may be understood as historical 'fact'; historiography may freely borrow the narrative conventions of any or all of those genres." See "Functions of Fiction in Historical Writing," in Writing Medieval History, ed. Nancy Partner (London: Hodder Arnold, 2005), 109, 111.
} 
Viewing the History as a biography is problematic in light of the modern expectations of a work of that genre. The term is unable to convey not only an accurate idea of the content of the History but also disguises one of the key functions of the History as a living document: the active engagement of contemporary concerns. ${ }^{44}$ Jay Rubenstein's observation that "the life depicted in a biography is ultimately inseparable from the life of the biographer. All writing may not be autobiography...but all biography to some extent is autobiography," is particularly relevant to the History and medieval historiography in general. ${ }^{45}$ Applied to the History, his observation serves to highlight the role of the patron and author in shaping the work and determining its content and aims. Furthermore, the expectations placed on a work of history by a medieval audience vary from our own. Suzanne Fleischman has observed that for most medieval chroniclers, "the determining criterion for what to include and what to omit was not so much a desire for objective and comprehensive reporting, but rather the function of the work-typically propaganda and/or panegyric." ${ }^{, 46}$ The History is not an attempt to record all of the details of Marshal's life; it is an account of his climb to social and political prominence. Fleischman's observation is evidenced by the particular choice of material included in the History. Focusing on the objectives of the text avoids the vexed question of genre (which

\footnotetext{
${ }^{44}$ Although all works of history are products of their own time, modern academic studies generally seek to depict a subject using the widest array of relevant material available in order to create as comprehensive a picture as possible. While a historian may engage in argumentation, the argument itself derives from the evidence available in the historical record. Historians may have a point to make and an interpretation to offer, but ideally the historical record directs this process. On the contrary, a medieval historian engaged in the writing of a work like the History sought to depict his subject in a predetermined manner. The value of the medieval historian's depiction of an individual derived from how closely the life and character of his subject was made to fall in line with expected norms, and, in the case of a commissioned work, how well the needs and interests of the patron were served.

${ }^{45}$ Jay Rubenstein, "Biography and Autobiography in the Middle Ages," in Writing Medieval History, 23.

${ }^{46}$ Suzanne Fleischman, "On the Representation of History and Fiction in the Middle Ages," History and Theory 22 (1983): 301.
} 
was fluid anyway), as well as the artificial isolation of the History from other contemporary works. By commissioning the History the young Marshal was responding to the requirements of his own individual situation, but he was utilizing a common medium. Given the wide range of contemporary historical writing, the uniqueness of the History noted by some historians may not in fact be so unique.

There are so many texts that could be called biography or biographical that the term loses nearly all its meaning in relation to medieval writings. Some historians dealing with these works have consciously chosen to avoid either the term biography or the term vita for texts dealing with political and aristocratic subjects. Taking royal histories as an example, Richard Cusimano and John Moorhead chose to title their edition of Suger's untitled work about Louis VI The Deeds of Louis the Fat, because "Suger sought to compose not a life of Louis but an account of his deeds. ${ }^{, 47}$ In a similar vein, Edmund King has commented about the Gesta Stephani that it is more a history of the events of King Stephen's reign than a biography. ${ }^{48}$ Although only in passing, King offers a characterization of the Gesta that can be applied to other works. The Gesta, he writes, "if not a biography, still sees the king as its central point of reference." ${ }^{49}$ The single figure as organizing principle and raison d'être for many historical works—a character who nonetheless often fades into the background or disappears from the narrative entirely for certain spaces—is not the same biographical character that a modern reader expects. King's concept of the individual as a central point of reference helps explain how, even in

\footnotetext{
${ }^{47}$ Suger, The Deeds of Louis the Fat, trans. Richard Cusimano and John Moorhead (Washington, D.C.: Catholic University of America Press, 1992), 6.

${ }^{48}$ Edmund King, “The Gesta Stephani," in Writing Medieval Biography, 750-1250, 197.

${ }^{49}$ Ibid., 204.
} 
a work like the History, in which Marshal is more frequently present than the title characters of other works, additions to the text which may seem irrelevant in accordance with the modern idea of biography make frequent appearances.

Twelfth and early thirteenth-century England witnessed the production of other works that historians have included under the umbrella label of biography. Many of these are clerical and include the hagiographical vitae of Thomas Becket and Adam of Eynsham's Life of St. Hugh of Lincoln.$^{50}$ Any distinct lives of the Plantagenet kings are conspicuously absent, and biographical material relating to them is found only within larger chronicles. ${ }^{51}$ In France, however, the output of royal histories remained continuous from the time of Louis VI. ${ }^{52}$ Nicholas Vincent has posited that Thomas Becket's murder effectively prevented Henry II from being made the subject of any panegyric or laudatory history, and the fraught family relationships of his sons and their political struggles likewise made them unlikely candidates for praise. At the same time, in comparison to the Capetians, the Plantagenets enjoyed stability on the throne of England that resisted the need for historically-minded propaganda or reinforcement until the final downturn of King John's reign. ${ }^{53}$

Aristocratically-sponsored histories like the Anonymous of Béthune's L'Histoire des Ducs de Normandie et des Rois d'Angleterre were also more prevalent in France than England. One explanation for this disparity is the different political and social trajectories

\footnotetext{
${ }^{50}$ For an analysis of the many Becket vitae, see Frank Barlow, Thomas Becket (Berkeley: University of California Press, 1986), 2-9. For the clerical nature of English biographical works, see Vincent, "The Strange Case of the Missing Biographies," 249-250.

${ }^{51}$ Vincent, "The Strange Case of the Missing Biographies," 255-256.

${ }^{52}$ Ibid., 255.

${ }^{53}$ Ibid., 254-255.
} 
of the two royal houses and their corresponding baronages. Before King Philip Augustus, the Capetian monarchs were not in a position of strength in relation to the barons of the surrounding territories. The Capetians relied on marriage alliances with their subjects and the promotion of their dynastic image as most pious Christian kings to bolster their position and increase their control of the baronage. During the reign of Philip Augustus, the baronage began to react to the changing power dynamics, and the writing of history became an important avenue for expressing and strengthening their identities and roles. Gabrielle Spiegel explains that, "the prescriptive authority of the past made it a privileged locus for working through the ideological implications of social changes in the present and the repository of contemporary concerns and desires." ${ }^{54}$ Spiegel's observation is relevant to both French and English medieval historiography, although in England, the power of the baronage was increasing in relation to the crown.

The prose form which the histories commissioned by some of the French aristocracy took is a critical piece of the picture for Spiegel. She has argued that the traditional use of verse vernacular became discredited as a mode of truth-telling, unfit for the writing of history. She has attributed this shift in thinking to medieval society's gradual transition from an oral culture to one which depended on texts. ${ }^{55}$ More recently, Leah Shopkow has noted the localized nature of history production. She has written that "once a dynastic history had been produced, other histories produced in the area or in contiguity were likely to adopt the form. In other words, existing texts served as models

\footnotetext{
${ }^{54}$ Gabrielle Spiegel, Romancing the Past: The Rise of Vernacular Prose Historiography in ThirteenthCentury France (Berkeley: University of California Press, 1993), 5.

${ }^{55}$ Ibid., 68.
} 
for other similar works." $" 56$ This may help to explain why the History was written in verse, which in Spiegel's view was already beginning to become outmoded in the early thirteenth century, at least in France. History writing in the vernacular was deeply rooted in the historiographical tradition of England, and the practice of writing in verse was well established in the twelfth century. ${ }^{57}$ Regardless of the form, historical works were largely purpose-driven, living documents intended to interact with contemporary concerns.

In England, the events of King John's reign and the tension of the opening years of the reign of Henry III did not provoke the same flurry of patronage in the baronage as occurred in France. The History of William Marshal stands alone as a work of baronial history among monastic chronicles and the works of historians like Gerald of Wales and Roger of Wendover. While relatively isolated, the History does bear the imprint of the romance tradition, in sharp contrast to the trend in historical writing on the Continent. Indeed, M. Dominica Legge has observed of the poet John's description of his work as "del conte l'estorie," that estorie can be translated to mean both "history" and "story," but that the latter is the preferable translation. Even the meter in which the History is written was normally utilized for the writing of romances. ${ }^{58}$ The title of the work-the History of

\footnotetext{
${ }^{56}$ Leah Shopkow, "Dynastic History," in Historiography in the Middle Ages, ed. Deborah Mauskopf Deliyannis (Leiden: Brill, 2003), 233.

${ }^{57}$ Significant verse histories written in twelfth-century England include Wace's Roman de Brut and Roman de Rou, and Gaimar's Estoire des Engleis. For the tradition of vernacular and verse historiography in England, see D. B. Tyson, "Patronage of French Vernacular History Writers in the Twelfth and Thirteenth Centuries," Romania 100 (1979): 190-196.

${ }^{58}$ M. Dominica Legge, Anglo-Norman Literature and Its Background (Oxford: Clarendon Press, 1963), 30, 308. For the poet John's words, see the History of William Marshal, 2:462. More recently, Peter DamianGrint has argued that, at least among twelfth-century historians, the term was used both to refer to authoritative sources and new works of history, suggesting that the same level of credibility was being claimed by the authors of new material. He has defined the term as "a narrative of past events, presented as true, and whose authenticity is attested by an authority." See Damian-Grint, The New Historians of the Twelfth-Century Renaissance: Inventing Vernacular Authority (Woodbridge, Suffolk: Boydell Press, 1999), 221, 255.
} 
William Marshal - perhaps points to the versatility of the word estorie and the complicated mélange of history and fiction present within the work. ${ }^{59}$ There apparently was no need for a clear distinction in order for the History to be considered truthful by its contemporaries. On to this observation can be added Spiegel's point that medieval histories should be viewed as "both literature and fact, or, more nearly, as literatures of fact.. ${ }^{\prime 0}$ The presence of romance elements is another reason why the label of biography is problematic in respect to the History, but such elements also served to support the desired image of Marshal.

The romantic elements of the History are most apparent in the first half of the work, which is concerned to show the good qualities that Marshal possessed from a young age and how they came to be recognized by his patrons and an ever-wider circle of contemporaries. Within the History, it is as the embodiment of the chivalric ideal that Marshal catches the attention of potential patrons. The historical details of the relationship between Marshal and his patrons are less carefully depicted than in the second half of the work. Marshal is given the role of tournament tutor to Henry the Young King, eldest son of Henry II, and the History recounts myriad tournament-related exploits undertaken by Marshal. The romantic embellishments and descriptions that run throughout this part of the work and the difference in detail are present largely due to the fact that the events of Marshal's early years had passed beyond the realm of living memory. Rather than a stream of historical events, this section often appears to be a

\footnotetext{
${ }^{59}$ A. J. Holden records that the three other manuscript copies of the History known to have existed in the Middle Ages were referred to variously as a liber, historia, and livre in medieval catalogs. Another but less likely match, in Holden's opinion, was referred to as a romaunce. See Holden, "Textual Introduction," 11. ${ }^{60}$ Gabrielle Spiegel, The Past as Text: The Theory and Practice of Medieval Historiography (Baltimore: Johns Hopkins University Press, 1997), 100.
} 
collection of well-known and celebrated anecdotes linked together by the common theme of tournaments and interspersed with historical context (like the conflicts between Henry II and his sons). ${ }^{61}$ Although the poet still interjects his narrative with references to sources and comments regarding the reliability of those sources, a significant source of authority for the depiction of Marshal's early years was romance literature.

The influence of romance literature discernible within the History ranges from simple character references to descriptive and more substantial story elements. David Crouch has found references to works belonging to literary collections ranging from the Romance of Alexander to the Romance of Guy of Warwick within the History. ${ }^{62}$ Some of the poet's references are straightforward. He compares Henry the Young King's deeds to those of Arthur and Alexander, for instance, and writes that Chinon "still retains the name it got from Kei. ${ }^{, 63}$ Crouch notes that Marshal's title—-the best knight in all the world—is borrowed from Guy of Warwick, and that the description of Marshal's personal appearance in large part conforms to the conventions of romance literature. But in Crouch's estimation, the subject within the History most heavily influenced by the conventions of romance is the tournament, and he is not the first to make that observation. $^{64}$

\footnotetext{
${ }^{61}$ For the role of family memories in the first half of the History and its pericopic structure, see Crouch, "Writing a Biography," 230-232.

${ }^{62}$ Ibid., 222.

${ }^{63}$ See History of William Marshal, 1:183 for Arthur and Alexander; and pg. 401 for Sir Kei. Geoffrey of Monmouth attributed the founding of Chinon to Kei. See The History of the Kings of Britain, trans. Lewis Thorpe (London: Penguin Books, 1966), 257.

${ }^{64}$ Crouch, William Marshal, 10-11. On the subject of the relationship of the History to the Guy of Warwick literature, Dominica Legge proposed that Marshal's life may have served as inspiration for the fictional Guy. See Anglo-Norman Literature and Its Background, 170. Crouch has commented that "perhaps the Pembrokes were sneering at the pretensions of the Warwicks, pointing to a real-life hero in their family tree, not a myth." See William Marshal, 11.
} 
On the subject of tournaments, Larry Benson has discussed the similarities between those depicted in the History and those in the work of Chrétien de Troyes. Chrétien's works were responsible for making the tournament a stock episode in romance literature, predating the History by more than fifty years. Chrétien's tournaments thus served as a representational precedent for the author of the History. Benson classified the History as the forerunner of the genre of chivalric biography and explained that "the hero of such a work exemplifies in the present the virtues of the great heroes of the chivalric past, and as proof of this, he is shown engaging in the same activities as the heroes of romance," explaining the significance of the amount of space dedicated to tournaments in the History ${ }^{65}$ In order to represent Marshal as the embodiment of chivalric ideals, the poet "drew on the themes and conventions of romance." ${ }^{66}$ Although participation in tournaments was a historically important, even critical, aspect of Marshal's career, the poet turned to romance as the authoritative mode of depiction of such events. Chrétien initially utilized actual tournaments to create his romance versions, as there was no literary precedent when he began work, but he idealized them into quests for honor and glory. As Benson has explained, "Chrétien drew on real life for the details that authenticated his romances, that lent plausibility to his fiction. Jean [the author of the History] drew on romance for the details that authenticated his biography, that lent plausibility to his claim that his hero was a true model of chivalry." ${ }^{~} 67$ In this way, fiction

\footnotetext{
${ }^{65}$ Larry D. Benson, "The Tournament in the Romances of Chrétien de Troyes and L'Histoire de Guillaume le Maréchal," in Chivalric Literature: Essays on Relations between Literature and Life in the Later Middle Ages, ed. Larry D. Benson and John Leyerle (Kalamazoo: Medieval Institute Publications, 1980), 19. ${ }^{66}$ Ibid.

${ }^{67}$ Ibid., 20. Specifically, Benson discusses the influence of Cligès, Lancelot, and Le Conte du graal on the History.
} 
and fact became intertwined to support the veracity of the claims of the History mutually. The use of romance conventions rendered Marshal's early years accessible and recognizable to the poet's audience at the same time that it promoted his representation of Marshal as an ideal character.

As Benson discusses, there are two particular tournaments in which elements of romance literature are most strikingly present. At the first, Marshal participates without anyone knowing his identity. The History asserts that "many looked at him hard; / they had no idea who he was / and were very keen / to do him some harm and capture him." According to Benson, this story element echoes the romance "theme of the Fair Unknown who by sheer prowess proves his knightly worthiness," and, in accordance with romance convention, the tournament takes place early in the career of the hero. ${ }^{69}$ The History goes on to relate that "not for a moment did he [Marshal] have gain in mind; / rather his mind was so set on noble exploits / that he had no concern for making profit.. ${ }^{, 70}$ His disregard for financial gain is also a key characteristic of a romance hero. ${ }^{71}$ The second tournament that Benson has indicated as owing a great deal to romance is the only one within the History to feature the involvement of women. Before the tournament began

The countess came out of the castle.

She was in face and body beautifully formed, so I have heard say, as only Nature could contrive her. With her were married ladies and young girls, so beautiful and adorned that as regards their beauty there was no room for criticism, nor had they anything to learn about courtliness or good sense.

\footnotetext{
${ }^{68}$ History of William Marshal, 1:153.

${ }^{69}$ Benson, "The Tournament," 20.

${ }^{70}$ History of William Marshal, 1:153.

${ }^{71}$ Benson, "The Tournament," 21.
} 
The knights rose up from the ranks

to meet them, as was fit and proper.

They were convinced that they had become better men

as a result of the ladies' arrival, and so they had, for all those there

felt a doubling of strength in mind and body,

and of their boldness and courage.

One of them said: 'Come on, let us dance

while we are waiting,

we will be less bored.'

So they took one another by the hand.

One man asked: 'Who will be

kind enough to sing for us?'

The Marshal, who had a good voice

but who in no way boasted about it,

then began to sing a song

in a pure, sweet tone. ${ }^{72}$

In both tournaments Marshal is highly successful and magnanimous in victory; in the first example he is the reluctant recipient of a pike and in the second he freely gives much of his hard-won booty away. ${ }^{73}$ However, as Benson has also noted, Marshal did fight for gain, and this fact is not hidden by the History. Rather, these initial tournaments, in which Marshal is represented purely as a romance hero, "set the tone of William's character for the whole work." ${ }^{74}$ The description of tournaments in the History becomes less romantic, but the character qualities claimed for Marshal in the romantic episodes remain the same in all aspects of his career.

Although Marshal is the focus of the History, he is not the only idealized character. In depicting members of Marshal's family, the History is careful to bestow on them qualities similar to those of the work's hero. The narrative of the History in fact begins with an account of the involvement of Marshal's father John in the events of the

${ }^{72}$ History of William Marshal, 1:177.

${ }^{73}$ For the pike, see ibid., 159-161; and for Marshal's generosity, see ibid., 181.

${ }^{74}$ Benson, "The Tournament," 23. 
civil war between King Stephen and Empress Matilda. John Marshal embodies many of the traits found in his son, and the History represents him as the lynchpin of the empress's cause, foreshadowing his son's role as an indispensable advisor and servant of the Plantagenet monarchs. In the civil war, the History claims that "King Stephen had the worst of it, / for, indeed, the worthy Marshal entirely / threw his lot in with the rightful heir." ${ }^{, 75}$ John Marshal endured much suffering and sacrifice in the service of the empress, introducing the important theme of being tested in royal service. Indeed, the History recalls forthrightly that "there was many a combat and battle for him, / many a trial and tribulation / he suffered on her [Empress Matilda's] behalf, many a hardship too, / before things were settled." ${ }^{, 76}$ John lost an eye after being cornered in a church that was set alight by the king's army, but only after "the whole army fell on him / in such a mighty charge / that he could no longer withstand it." 77 He had, according to the History, made a stand by a ford, but was forced to retreat to the church with a single companion. His loyalty and personal sacrifice create the sense that the qualities so well developed in the character of his son throughout the History are in fact shared family attributes.

Scenes like that of John Marshal facing down King Stephen's army provide abundant indication that John the poet had a flare for the romantic that transcended tournaments, especially when the living memories of his informants were not likely to get in the way. In order to mark William's entry into the realm of real combat, the History relies markedly on romantic embellishments. Fighting for his cousin, William de

\footnotetext{
${ }_{76}^{75}$ History of William Marshal, 1:5.

${ }^{76}$ Ibid.

${ }^{77}$ Ibid., 15.
} 
Tancarville, amidst the houses of Drincourt, the History relates that Marshal lashed out independently but was soon rendered aid thanks to the cries of worried onlookers, for:

At the windows and in upstairs rooms were ladies and knights, and many a burgher with his wife, who were much pained and aggrieved to see the Marshal with no help around him. Then up went the unanimous cry: "Normans, you do wrong not to go to the Marshal's aid.

It is a source of much pain and sadness to us that he fights in such a sorry plight."

Heralds, whose task it was to relate feats of arms, and minstrels out in front to witness the fine blows dealt and tell of them, set out after him, shouting:

"Over here all of you, to the brave knight's side! This man doesn't hide away, he makes great companies buckle before him, he cuts a swathe through the ranks; he is a man whose blows strike home everywhere, a man who doesn't hold back, before whom lance and sword offer short resistance. He's one who hasn't sworn a peace accord."78

Here, the romantic and fanciful elements (the dubious presence of heralds and minstrels in the thick of battle and the support of Marshal by the spectators) also confirm the critical theme of external advocacy that runs throughout the History. Most of the romantic elements present in the first half of the History create the sense that the memory of Marshal's early years had come to be mythologized within the family, and the first half of the History is a significant repository of positive family memories of Marshal, most of which deal with his time on the tournament circuit. Comical anecdotes, such as Marshal capturing a knight only to have him escape by clinging to a low-hanging gutter as

\footnotetext{
${ }^{78}$ Ibid., 51.
} 
Marshal led his horse along, punctuate the narrative. But even these stories are often used to highlight his humility and loyalty. After one particular tournament Marshal was deemed by the high-ranking men there "to be without equal, / for you would not find his like / as regards fine words and deeds, / nor would you find a man anywhere / less boastful about himself.,79

The idealization and stasis of Marshal's character are traits that are by no means only comparable to figures found in the genre of romance literature. Spiegel has described the ideal hero as "immutable," a trait shared by Marshal in the History and many other medieval characters. ${ }^{80}$ Speaking of the writing of medieval biographical works broadly, Rubenstein avers that "biographers have preconceptions about how a life ought to be led...The Life which they present is a life designed to demonstrate those ideals in action." ${ }^{81}$ His description of the standard depiction of protagonists within hagiographies also closely resembles the depiction of Marshal. Within hagiographies, there is "never need to doubt the core virtue of the protagonist" and "the paths they walk, though filled with obstacles, neither fork nor break." ${ }^{82}$ Jean Blacker has explained that within many medieval histories, "individual character was seen as composed of separate traits, which did not admit of variation in and of themselves but appeared in various combinations, as individual colors in a kaleidoscope." ${ }^{83}$ Whether a work was meant to enumerate the exploits of an exemplary hero, demonstrate the sanctity of a particular individual, or provide an account of the career of a person like Marshal, the similarities in

\footnotetext{
${ }^{79}$ Ibid., 161.

${ }^{80}$ Spiegel, Romancing the Past, 154.

${ }^{81}$ Rubenstein, "Biography and Autobiography in the Middle Ages," 34.

${ }^{82}$ Ibid., 25-26.

${ }^{83}$ Blacker, The Faces of Time, 56.
} 
character depiction across works indicate that an audience had certain expectations, even when the ostensible purpose of a work was historical verity. Indeed, the consistency of the character may have been viewed as a guarantor of accuracy akin to the role of precedent in other aspects of medieval culture. ${ }^{84}$

This manner of character representation also begs the question of in what manner a work like the History can be considered propaganda, if, as Fleischman suggests, "for the Middle Ages and even well beyond, historical truth was anything that belonged to a widely accepted tradition." 85 The Marshal family naturally wanted to commission a work that celebrated its most successful member, and the character traits that Marshal exemplifies within the History explain his success. Within the practice of medieval historiography and literature, character nuance was not commonly depicted, so although the portrait of Marshal in the History is highly favorable, it is not necessarily distinctive, raising the question of whether character depiction was a particularly effective mode of propaganda, or of disseminating the family's vision of its ancestor. Instead, the depiction of events, omissions from the narrative, and distinctive details (when present) may be the more reliable indicator of the work's purpose in setting down a version of the past most suitable to the needs of the young Marshal. The manner in which his father needed to be depicted was in some sense already determined by precedent and available character molds, and the events of his career needed to be made to conform to the ideal character traits that he embodied. Marshal's character within the History may have been expected, even predictable, to a medieval audience, but the ways in which the events and details of

\footnotetext{
${ }^{84}$ For a similar point in regard to hagiographies, see Thomas J. Heffernan, Sacred Biography: Saints and Their Biographers in the Middle Ages (New York: Oxford University Press, 1988), 20.

${ }^{85}$ Fleischman, "On the Representation of History," 305.
} 
his life unfolded to uphold and conform to the representation of his character may not have been. So, whereas Marshal's character carried the authority of conforming to wellknown ideals, the content of his story-ranging from his support of the Young King in tournaments to his acquisition of the regency — formed the truly propagandistic elements of the History.

Within the context of Fleischman's observation about historical truth in the Middle Ages, the History can be interpreted as the first step in the creation of an accepted tradition. Family memories and information pertaining to Marshal were gathered and set down in writing in order to be disseminated by the reading or performance of the text, which facilitated the creation of living memory. It cannot be argued that physical copies of the work were widely disseminated, since evidence of only a few medieval copies exists. ${ }^{86}$ The poet John was concerned with textual authority; he refers to written sources. But most people experienced his work by hearing it, and it cannot be forgotten that a great deal of the value of the work to the Marshal family rested on this factor. Through the act of reading the History aloud, the reader takes on the authorial voice, as the poet interjects his narration with comments written in first person. Thus, the authority of the text's claims is reinforced through the voices of various readers. The most striking example of this is an authorial interjection in which the poet wrote that further discussion of the events of the First Barons' War "might result in harm to myself." ${ }^{\text {, }}$ Such an avowal likely communicates the stance of young Marshal on discussion of his involvement in the rebellion, although he was not responsible for the poet's choice of words. The repetition

\footnotetext{
${ }^{86}$ For the copies, see Holden, "Textual Introduction," 11.

${ }^{87}$ History of William Marshal, 2:253.
} 
of such a phrase over the course of multiple readings helped ingrain a politic silence on the matter.

The concept of the living document can be applied to the physical History as well. The modern approach to history writing, whether in the form of biography or any other form, is the production of individual works that relate to other works through scholarly discourse conducted by referencing others' ideas. This too occurred in the medieval period, but individual works were also frequently modified, copied, or continued in a manner almost unheard of today by hands other than those of the original author. An example of this from a medieval genre loosely resembling biography is the saint's life. Robert Bartlett has observed that vitae could be rewritten for stylistic purposes, or in response to political or cultural change. ${ }^{88}$ It is conceivable that a work like the History could have been expanded or augmented by other Marshal family commissions at a later date, especially since it is in some ways a proto-genealogy for the Marshal family. The narrative begins by providing a family context for Marshal with information about his father John Marshal and the story of his two marriages and children, and the second half of the work includes an account of the marriages of William Marshal's children. Spiegel has observed that, "written above all to exalt a line and legitimize its power, a medieval genealogy displays a family’s intention to affirm and extend its place in political life." 89 The purpose of the History cannot be said to be primarily genealogical, but the presence of the whole family within its pages and the emphasis placed on shared family attributes indicates that genealogy was a concern, and one that could be expanded upon in the

\footnotetext{
${ }^{88}$ Robert Bartlett, "Rewriting Saints' Lives: The Case of Gerald of Wales," Speculum 58 (1983): 598-599.

${ }^{89}$ Spiegel, The Past as Text, 104.
} 
future. Young Marshal's marriage into the royal family emphasized the importance of family ties at a moment when, as Spiegel so aptly described it, the family was extending its influence.

The History was a living document in many ways: it bore the possibility of expansion or augmentation; it was designed to address the concerns created by young Marshal's political situation; and it was a means of actively creating a Marshal family tradition that promoted a particular view of the past meant to influence the present and future generations. Labeling the History a biography obscures the dynamic purpose of the text and imparts unrealized expectations. Its content neither conforms to modern expectations in terms of breadth nor detail, and its incorporation of non-historical elements certainly does not conform to modern ideas. The label of biography simply does not do the work justice. Instead, it focuses attention solely on the titular subject of the work and explains why the History has escaped sustained scrutiny and has been used almost solely as a source of information despite the recognition by historians of the importance of exploring the impetus behind the creation of histories. The vast amount of work committed to the study of patronage and historiography in the twelfth and thirteenth centuries and beyond has highlighted the importance of history in the political and social ambitions of baronial and royal families. Although David Crouch has dedicated some thought to exploring these issues in relation to the History, the amount of attention given to it is minimal, despite the importance placed on patronage by historians generally. An examination of the events of young Marshal's career can reveal why he found it expedient to commission the History. 


\section{Chapter Two: \\ William Marshal, $2^{\text {nd }}$ Earl of Pembroke}

No narrative sources exist for the life of the young Marshal. His name appears fleetingly in contemporary chronicles (although mention by name at all is often significant in those sources), and no historian has ever written an account of his career. In the broad political histories of Henry III's reign published in recent times his appearances are little more sustained, and it is difficult to gain a substantive picture of him. By the year 1226 nearly all mention of Marshal has disappeared. But these texts are written largely from the perspective of the royal government and its most important servants, and only illuminate the individual baron when he comes into direct contact with the king's service, oftentimes in conflict. Marshal and others like him were far more significant on an individual basis than these accounts might indicate. Nicholas Vincent, in his biography of the young Marshal's contemporary, Peter des Roches, has acknowledged Marshal's influence. Vincent summed up the Marshal's power from the posthumous perspective of the rebellion of 1233-1234, writing that "it is no exaggeration to say that England was plunged into civil war between the king on one side, and on the other the household and affinity of a dead man, William Marshal II."90

While the History of William Marshal has little to say about the young Marshal directly, its existence has a lot to say. Hints as to why Marshal commissioned the work can be found in the documents pertaining to his career and relationship with the royal house. In particular, letters and court records reveal his conflicts with fellow barons and

\footnotetext{
${ }^{90}$ Nicholas Vincent, Peter des Roches: An Alien in English Politics, 1205-1238 (Cambridge: Cambridge University Press, 1996), 403.
} 
his attempts, along with those of the government, to find a balance of power. Marshal fought to retain the properties that he felt were his and achieve his unconventional marriage, and at times the records illustrate the great frustration that he experienced. The surviving, accessible documents are limited in scope and cannot be used to construct a complete account of the young Marshal's life. Most of the sources are products of the period between 1219 and 1224 . Despite their limitations, they do pertain to the subject matter of the History, which is largely a story about one man's political career and above all, his political relationships. These documents, combined with the narrative background of the reign of Henry III provided by historians such as David Carpenter, Maurice Powicke, and Kate Norgate, add depth to the story behind the History only hinted at by modern biographers of the elder Marshal. They explain why a former rebel and powerful baron commissioned a work dedicated to demonstrating the persistent interconnection between his family and the royal house.

Born in Normandy in 1190, the young William Marshal was the first of ten children. There are no sources that provide a glimpse into his childhood, and the History makes no mention of his early years except to take note of his birth and that of his siblings. His introduction to the tensions of King John's reign came early. As a young man he was a political hostage held at the king's court between the years 1205 and 1212. ${ }^{91}$ He owed his stay at court to his father's strained relationship with the king during the years leading up to Magna Carta. William entered the political arena on his own footing during the First Barons' War of 1215-1217, initially fighting opposite his father and King John as a member of the rebellion. His involvement warranted the notice of

\footnotetext{
${ }^{91}$ Crouch, William Marshal, 99, 117.
} 
contemporary chroniclers and eventually the pope, marking the beginning of a short but tumultuous career. Thus the younger Marshal's story, to the extent that it can be reconstructed with any detail, begins with the First Barons' War.

The road to war began before John became king in 1199. The extreme financial pressures of King Richard's reign had already taken a toll on the resources of the Plantagenet lands, and John inherited an exhausted and increasingly war-weary realm. ${ }^{92}$ Richard had been engaged in war against King Philip II of France since his return from the Third Crusade, and had died in the midst of the conflict. While Richard had maintained the relatively powerful position that the Plantagenet kings held in relation to the Capetians as kings of England and lords of the western half of France, the situation was soon reversed. The treaty of Le Goulet, established between John and King Philip upon John's accession, left John a noticeably weaker king than his predecessors and foreshadowed a downhill slide in his fortunes that continued throughout his reign. ${ }^{93}$ Although it would be a mistake to give the label of inevitability to the events of John's reign, he inherited serious challenges from his brother, not least of which was the discontent of his barons over their financial burdens. The question of whether or not they would support him if and when struggles with the French resumed was an open one.

Conflict did resume, and in 1202 Philip formally deprived John of Aquitaine, Poitou, and Anjou before entering Normandy in force. John's refusal to obey a summons

\footnotetext{
${ }^{92}$ Expenditures on the Third Crusade, Richard's ransom after he was captured on his return from the Holy Land, and war with King Philip II of France that was near-constant after Richard arrived home were all contributing factors.

${ }^{93}$ Two of the most damaging aspects of the treaty for John were the requirement that he pay a 20,000 mark relief to King Philip in order to claim his inheritance and that his relationship to some of his vassals became subject to mediation by the French king. See W. L. Warren, King John (Berkeley: University of California Press, 1978), 55.
} 
and the ensuing diplomatic wrangling caused Philip to sever his ties with John. The conflict resulted in the loss of Normandy in 1204, due in no small part to the Normans themselves, who abandoned John with little hesitation. That same year the death of John's mother, Eleanor of Aquitaine, provided Philip the opportunity to move against the southern lands of the Plantagenet house, since he had had no actual legal right to claim them while Eleanor still held them as her own. Once John held Aquitaine, however, Philip was free to continue annexing the French holdings of the English king. ${ }^{94}$ Unfortunately for John, he alone was tied to Aquitaine. None of his English barons had any claim to the land or personal interest in its fate. They were unwilling to expend their resources and energy to assist their king in the matter.

Normandy was an altogether different situation. Unlike the lands further south on the Continent, many English barons did hold land in Normandy and had an acute interest in the goings-on there. When Philip captured Normandy, many of John's barons were left with a difficult choice. They could abandon their English lands and do homage to Philip, they could leave their Norman lands in favor of their English properties and John, or they could attempt to maintain loyalties on both sides of the English Channel. The last of these options proved the most appealing to many barons, and both kings earned money from desperate noblemen paying for the privilege of retaining control of their properties, at least for a time. The technicalities of such a situation remained to be worked out, however, and we know that William Marshal senior was able to pay to maintain his

${ }^{94}$ Warren, King John, 101. 
Norman lands for a year and a day, after which he would be required to do homage to Philip. $^{95}$

Tension continued to mount in England as John scrambled to prepare his country for war and to face a rumored invasion by the French. During this atmosphere of unease, Marshal's year and a day passed and he was in need of a fresh agreement with Philip. Traveling to the Continent, he met with the French king and did homage to him specifically for his Norman lands. The implication was that Marshal owed service to Philip and to John simultaneously, and following his homage to Philip, the senior Marshal did refuse to aid John militarily in Poitou. The English king now saw Marshal as a man with divided loyalties, and perhaps as a representative of the lack of loyalty he suspected in his barons more generally. ${ }^{96}$ The conflict between John and Marshal that arose over the latter's actions was in part settled when Marshal agreed to hand over the young Marshal as a hostage.

As John's reign continued, the financial burdens imposed by the king on his barons and the pressures of war became increasingly odious to the English nobility. By 1214 , a large number of barons refused to serve John militarily on the Continent or pay scutage in lieu of participation. Aggravation over John's reliance on foreign mercenaries and his promotion of these men and others not native to England to positions of importance within the government added to the unrest. The sense that offices traditionally held by the baronage were being usurped, unfair financial burdens imposed, and military

\footnotetext{
${ }^{95}$ Ibid., 104.

${ }^{96}$ Ibid., 114. See also Crouch, William Marshal, 96.
} 
service required only for the benefit of the royal house combined along with myriad smaller factors to produce open rebellion. ${ }^{97}$

Despite the elder Marshal's strained relationship with John, he stalwartly supported the king in his struggle with his subjects, along with all of the most powerful of John's magnates. W. L. Warren has observed, however, that the baronage was not clearly divided. The majority hesitated and wavered between positions of rebellion and loyalty, and oftentimes families split, with supporters on both sides. The rebellion against John remained a war of words until, in May 1215, the rebels attacked the castle of Northampton in retaliation for John having rejected demands, which, unfortunately, have been lost to history. After failing to take the castle the rebels moved on to London, picking up the castle of Bedford along the way. London received the rebels willingly. Despite this significant victory, the militant dissidents did not have the support that they needed for prolonged success. With the rebels trapped in London and faced by John and his army, there was time for more talk. In Warren's estimation, the majority's unwillingness to take a firm stand resulted in Magna Carta in 1215. If the rebels had succeeded in swaying the majority, John would have been forced to quash them, but hesitancy opened the door for negotiation. At the same time, the more moderate rebels benefitted by appealing to those loyal to the king with a non-violent approach to their grievances. ${ }^{98}$

Young Marshal, having been free of the royal court for three years, sided with the rebels. St. Albans monk Roger of Wendover recorded "William Marshall junior" on a list

\footnotetext{
${ }^{97}$ Warren, King John, 225-226.

${ }^{98}$ Warren, King John, 231-232 and 234-235.
} 
of "the chief promoters of this pestilence" in the period immediately leading up to Magna Carta. ${ }^{99}$ Wendover's account includes a papal order of excommunication issued by Innocent III. Marshal was one of thirty-two individuals named by the pope in the order. ${ }^{100}$ The letter arrived in England after the creation of Magna Carta in July, and only heightened tensions between John and the barons. There were members of the baronial party who were not satisfied by the charter and who continued to push for armed hostilities, and the order of excommunication fed the flames. It was not long before dissatisfaction erupted into sustained warfare. ${ }^{101}$

The invasion that John had feared but had never materialized became a reality. In search of a rival king, the rebels invited King Philip's son Louis to sail to England and claim the throne. After a period of deliberation, Louis set out to join the rebels in May 1216. Initially, his French army galvanized the English rebels and led to yet more defections from among John's adherents (Warren placed the number of Louis's supporters at two-thirds of the English baronage). However, Louis's success was not long-lived. He and his army quickly began to alienate their English confederates with their accumulation of English lands. Some English rebels began to abandon Louis and return to John. ${ }^{102}$

The young Marshal's relationship with Louis also began to sour, and Louis was unable to retain his loyalty for long. Marshal claimed the custodianship of the castle of Marlborough after Louis gained control of the fortress, and he also claimed the right to

\footnotetext{
${ }^{99}$ Roger of Wendover, Roger of Wendover's Flowers of History, Comprising the History of England from the Descent of the Saxons to A.D. 1235, trans. J. A. Giles (London: Henry G. Bohn, 1849), 305.

${ }^{100}$ Ibid., 354-355.

${ }^{101}$ Warren, King John, 244-246.

${ }^{102}$ Ibid., 252-253.
} 
fill the office of marshal. Although Louis had given the office to another, he recognized Marshal's claim. He did not, however, concede the castle. Since the Marshal family had a claim to Marlborough itself dating back to the young Marshal's grandfather and also held many other properties in the surrounding area, the loss of the castle in July 1216 was a blow to the family and something that was not tolerated for long. ${ }^{103}$

On October 18, 1216, King John died and his young son Henry became the focal point of the royalist cause. The child offered an English alternative to Louis and changed the face of the conflict. For many, allegiance to the boy was tenable whereas allegiance to John had not been. Henry was crowned just ten days after his father's death. Soon afterwards the senior Marshal became the regent by the agreement and solicitation of the royalist barons. ${ }^{104}$ Whether John's death and his father's ascendency influenced the young Marshal is unknown, but within two months Marshal and William, Earl of Salisbury, his good friend and the half-brother of the dead king, had begun to make overtures to the royal court. ${ }^{105}$ Both men waited until Louis had returned to France to seek assistance from King Philip in February 1217 before officially abandoning him. Upon Louis's return to England in April the young Marshal was ready and willing to enter hostilities on the royalist side. ${ }^{106}$

Young Marshal's entrance into the royalist camp proved lucrative. His new loyalty was acknowledged by the grant of the rebel earl David of Huntingdon's lands,

\footnotetext{
${ }^{103}$ David Carpenter, The Minority of Henry III (Berkeley: University of California Press, 1990), 29-30.

${ }^{104}$ Crouch, William Marshal, 125-127.

${ }^{105}$ Kate Norgate, The Minority of Henry III (London: MacMillan, 1912), 25.

${ }^{106}$ David Crouch, William Marshal, 128.
} 
including the castle of Fotheringay. ${ }^{107}$ Next, seeking to settle his grievance with Louis, he besieged the castle of Marlborough and wrested it from Louis's forces. Throughout the rest of the war he fought faithfully for the royalist cause. As regent, his father offered generous terms to those contemplating a return to their original loyalties, and eventually two important victories—at Lincoln and a sea battle near Sandwich—led Louis to agree to terms and leave England. ${ }^{108}$ After the conflict ended the young Marshal was granted 1,000 marks a year in order, as Carpenter puts it, "to sustain him in the king's service." The money came from the royal exchange. ${ }^{109}$

The political landscape after the war continued to be one of instability for all parties as relationships came to be defined and the government of the new king sought to establish its authority vis-à-vis the English, Welsh, and Irish barons and the Continental powers, including the French king and the pope. One theater of enduring importance was property, both for the barons and the king. The relative chaos of the war had shifted the control of properties just as it had loyalties and left the king with less control than he would like and some of the barons with more control than he, or other barons, could countenance. As Robert Stacey has explained, "royalist commanders had had ample opportunity during the war to capture and retain the lands, offices, and castles of defeated rebels and even of absent royalists." Many of these barons had created substantial powerbases for themselves, threatening the maintenance of royal rights and authority within the lands that they held. One castellan in particular, Falkes de Bréauté, became an antagonist of the young Marshal and eventually the government. Falkes was not only

\footnotetext{
${ }^{107}$ Norgate, The Minority of Henry III, 152.

${ }^{108}$ Crouch, William Marshal, 134-135.

${ }^{109}$ Carpenter, The Minority of Henry III, 73, 77.
} 
sheriff of six counties, but also held seven castles and farmed "an enormous number of royal manors and hundreds." 110 Similar in some ways to the young Marshal's father, Falkes had risen up from obscurity in the service of King John and had even been named one of the executors of John's will. ${ }^{111} \mathrm{He}$ was also a Norman and as such, one of the foreign men whom John had promoted so controversially. ${ }^{112}$

The threat to King Henry's fledgling reign posed by his barons was widespread. Although the First Barons' War was over, the potential for violence remained. Private wars and disagreements between barons like Falkes and William, Earl of Salisbury, and the young Marshal and Salisbury (despite their previous friendship, to which they returned), created instability and shifting factionalism. A particularly wide rift existed between the justiciar Hubert de Burgh and the barons that he cultivated as allies, including the young Marshal, and Peter des Roches, the bishop of Winchester and the king's guardian, whose most high-ranking ally was Ranulf, Earl of Chester. The justiciar and the bishop offered competing avenues of approach to the king. It was Hubert whose task it was to ensure the return of the royal castles to the king's control and who steadily pursued an alliance with Marshal. ${ }^{113}$ Open rebellion did occur, as in 1220-1221, when the count of Aumâle seized the castle of Fotheringay, possibly in response to his loss of two royal castles, and in 1223, when the earl of Chester and several allies, including Falkes, attempted to seize the Tower of London. The latter incident was spurred by resentment

\footnotetext{
${ }^{110}$ Robert Stacey, Politics, Policy, and Finance under Henry III, 1216-1245 (Oxford: Clarendon Press, 1987), 10-11.

${ }^{111}$ Carpenter, The Minority of Henry III, 14, 20-21.

112 Warren, King John, 188.

${ }^{113}$ Stacey, Politics, Policy, and Finance, 16-18.
} 
over Hubert's overarching power and his castle policy. ${ }^{114}$ Most of the barons who held royal castles, including Marshal, engaged in varying degrees of disobedience and threat.

Upon his father's death in May 1219, William was granted the bulk of the Marshal lands, including most of the holdings in England, Pembroke and Striguil in Wales, and Leinster in Ireland. ${ }^{115}$ Certainly not immune to the growing conflicts surrounding the tangled web of property, the first of several lengthy battles embroiled the new earl of Pembroke soon after his father's death. Marshal became a particular concern for the new king due to his many significant holdings and his strong desire to retain what he held, even if it meant defying the king. Conflict arose over the castle of Fotheringay and the other lands of Earl David of Huntingdon that had been granted to Marshal during the war. In fact, Marshal had been ordered to return the properties to the earl almost immediately in 1218 , but he did not give up custody of the castle. When Earl David died his properties were supposed to revert to the king, but letters sent by Falkes de Bréauté reveal that Marshal's men were actively and defiantly acquiring more of the deceased earl's former holdings. ${ }^{116}$ Falkes became involved in the conflict over Earl David's lands by virtue of his position as sheriff of the affected counties, and also became embroiled in his own personal conflict with Marshal.

Falkes's first letter concerning the earl of Huntingdon's lands was sent to Hubert de Burgh, the royal justiciar, just days after David's death in June 1219 to inform him

\footnotetext{
${ }^{114}$ For Aumâle, see ibid., 22; and Ralph Turner, "William de Forz, Count of Aumale: An Early ThirteenthCentury English Baron," Proceedings of the American Philosophical Society 115 (1971): 238. For the earl of Chester and the Tower of London, see Stacey, Politics, Policy, and Finance, 28; Norgate, The Minority of Henry III, 204-205; and Maurice Powicke, The Thirteenth Century, 1216-1307 (Oxford: Oxford University Press, 1962), 24.

${ }_{115}$ David Crouch, William Marshal, 139. The family's Norman lands went to William's brother Richard.

${ }^{116}$ Ibid., 148-149.
} 
that "servants of William Marshal came, who were residing at Fotheringay, to the manor of Earl David in the county of Northampton, namely Yardley, and they lodged themselves there, taking possession on behalf of their lord." 117 The interlopers were first confronted by the sheriff of Northampton, but upon their refusal to obey his order to leave, Falkes became involved. He was hesitant, however, to act on his own. He told Hubert that he "should hate to undertake or do anything against William Marshal through which the dishonor of avarice or infamy could or ought to be attributed to me."118 It was Hubert's responsibility to "produce justice for each person" and come in person to "cause such presumptions and many others in those parts to be corrected." ${ }^{119}$ As David Carpenter has noted, Falkes and Marshal were involved in their own disagreements at this time, making intervention by a third party preferable in this instance. ${ }^{120}$ Moreover, Falkes probably wished to avoid prejudicing his own position when his struggle with Marshal came to court.

The fact that news of the plight of the former earl's lands had reached the highest rung of government is evidenced by Marshal's answer to the charges, directed to the king. Opening with his greetings and pledge of "ubiquitous faithful servitude," Marshal continued to address the king in tones of astonished indignation. "Having received and understood your letter, dearest lord," he wrote, "and with fitting allegiance, my soul was amazed more than it would be possible to be believed... because you wanted to believe

\footnotetext{
${ }^{117}$ Fawkes de Breauté to Hubert de Burgh, Justiciar (no. V), June 29, 1219, in Royal and Other Historical Letters, 1:4. The letter is misdated to 1217. See Carpenter, The Minority of Henry III, 149, n. 15 for the date of the letter and the same page for the modern location of the manor that Falkes names in the letter. The manor is called Gerdeslee in the Latin. All translations are my own unless otherwise noted.

${ }^{118}$ Ibid.

${ }^{119}$ Ibid.

${ }^{120}$ Carpenter, The Minority of Henry III, 149.
} 
that I had committed offense against your dignity and excellence; since at no time would I do or order anything to be done against your excellence and dignity, from whence the evil conjecture of suspicion would be able to take hold." To the specific allegations regarding property seizure he responded that "if this deed that I am thoroughly ignorant of was done by my bailiffs_-and I do not consent to deeds of this kind-I will cause the excesses of my bailiffs, if they did anything, to be emended according to your will, following the law and custom of the kingdom." ${ }^{121}$ Despite Marshal's self-avowed shock that the king would believe that he had ordered his men to take over crown properties that were not his to hold, the infringements continued. David's widow wrote to Falkes to complain, the sheriff related to bishop Peter des Roches and Hubert de Burgh, that "the bailiffs and servants of William Marshal came into her lands and ejected her" from three of her manors. $^{122}$

Soon after the complaints about Marshal's invasion of the earl of Huntingdon's lands, a major dispute over properties between Falkes and Marshal reached court. The battle centered on the ownership of four manors which Marshal wanted to reclaim from Falkes, whom he thought was holding them unjustly. William claimed that he had committed the manors to Falkes "according to his will," (i.e., to be held by Falkes as long as William saw fit) and the manors remained his by right. ${ }^{123}$ Unfortunately for William, the only physical evidence that he was able to produce was a charter of King Richard that granted the manor of Luton to Baldwin of Béthune. William thus claimed Luton in right

\footnotetext{
${ }^{121}$ William Marshal, Earl of Pembroke, to Henry III (no. XLI), Autumn 1219, in Royal and Other Historical Letters, 47.

${ }^{122}$ Fawkes de Breauté to Peter, Bishop of Winchester, and Hubert de Burgh, Justiciar (no. XL), Autumn 1219, in Royal and Other Historical Letters, 47.

${ }^{123}$ Curia Regis Rolls, ed. C. T. Flower (London: H. M. Stationary Office, 1938), 8:77.
} 
of his deceased wife, who had been Baldwin's daughter. Falkes claimed, however, that although King John had granted the manor to him during the period of William's rebellion, he had willingly returned it to William "when peace was made between the lord king and his barons" because he "did not wish to be against the common peace.", William had then, according to Falkes, given it back to him via charter. Falkes entered William's own charter granting him the manor as evidence in addition to letters patent in which William commanded one of his men to hand over possession of the manor to Falkes.

Falkes was able to offer similar evidence in relation to the other three manors.

The charter that Falkes presented at court ran as follows:

You should know, etc., that I, William Marshal, the son of William Marshal Earl of Pembroke, have given and relinquished to Falkes de Bréauté and handed over as his peaceful right and declared from me and from my heirs to him and his heirs my whole land that I held in the county of Kent, namely the manor of Brabourne, the manor of Sutton and the manor of Kemsing with all appurtenances and liberties and rights which pertain to the aforementioned manors, so that henceforth I or my heirs in the aforementioned manors ought not nor want to proclaim other right: and, if others wish to cause the aforenamed Falkes and his heirs injury or damage concerning the aforementioned land, I and my heirs can warranty to the greatest extent of our abilities the aforementioned land. For this, however, by gift and grant the aforementioned Falkes gave to me six times twenty marks of silver and one horse. ${ }^{125}$

The charter was witnessed and sealed. Like Luton, Falkes also presented letters sent by William commanding that Falkes be given possession of the manors in addition to letters patent that "the same earl directed to all of his knights from Kent, by which he firmly

\footnotetext{
124 Ibid., 249.

125 Ibid., 251. The names of the four manors have been given the modern names supplied by David Carpenter. See The Minority of Henry III, 165.
} 
commanded and admonished that, having considered the letters, they should perform homage and service to Falkes de Bréauté."126

In response to Falkes's claim about Luton, the Curia Regis Rolls record that William argued that "he did not compose that charter for him [Falkes]" and "he offers to defend [himself] against the same Falkes by his body... and he offers to the lord king 1,000 marks for having defense against him by his body or to demonstrate that this was done wickedly to disinherit him. And, if this does not suffice, he offers to place himself upon the named witnesses in the charter." As to Falkes's claims about the other three manors, William responded that "he never accepted the six times twenty marks from him nor any denarii nor the horse; and that he did not provide a charter for him, nor is it his seal." His response to the letter evidence was the same. ${ }^{127}$

Falkes, less than enthusiastic about the prospect of a personal duel, asserted that he would prove his case "either by the body of a certain free man...or by witnesses and other legal men of the vicinity and by the collection of other seals."128 The Rolls record after Falkes's statement that William, perhaps feeling the pressure of so much evidence against him, replaced his attorney with another. Whether this change had an effect or not, the next entry on the case records that an agreement was reached whereby Falkes was granted all four manors by William. However, Falkes was required to pay William 1,000 marks, give him all of the equipment from the four manors, and hand over four of his own manors to William, including all of the equipment. Unsurprisingly the two men's relationship remained hostile, and William did not give up his desire to regain control of

\footnotetext{
${ }^{126}$ Curia Regis Rolls, 8:251.

${ }^{127}$ Ibid.

${ }^{128}$ Ibid., 252.
} 
the four manors. ${ }^{129}$ It was not until 1225 that he once again came into possession of them. $^{130}$

This major case was accompanied by other, smaller disputes involving William

that took place during the same year or soon after. In one letter written to Hubert de

Burgh, Marshal's opening comments point to his frustration over his property squabbles.

Speaking on behalf of one of his men whose holding had been raided by Falkes's men-

they had carried off an unlucky individual along with carts and grain-William

admonished Hubert that "your sufficient discernment ought to agree, that all who are in

the service of the lord king should have peace concerning their lands, and at the same

time [their] holdings [should] not [be] harassed unjustly." "131 The next year William wrote

to Hubert to complain that "the sheriff and bailiffs of Falkes de Bréauté placed their

hands on my Bedfordshire lands; from whence I am greatly and rightly astonished."132

One potential reason for William's aggressive pursuit and defense of property was

his tight finances during the period following his father's death. The crown, likewise

\footnotetext{
${ }^{129}$ Ibid., 252 and Curia Regis Rolls, 9:205. Unfortunately there is no explanation as to how the concerned parties reached their settlement. William appears to have received the better deal, but there is no assessment of the values of the traded manors in relation to each other. Falkes's plethora of written evidence may have been convincing, since he did retain control of the four manors that he claimed were his, but written evidence did not necessarily carry more weight than oral testimony at the time of this case. Dependence on records was not a regular feature of legal proceedings (or in general) in England until the reign of Edward I (1272-1307). During the reign of Henry III, the testimony of witnesses was still quite common. Thus, William's request to "place himself upon the named witnesses" in the absence of written evidence was a nod to accepted practice. See M. T. Clanchy, From Memory to Written Record: England, 1066-1307 (Cambridge, Mass.: Harvard University Press, 1979), 19-20. The conclusion that his preference to duel Falkes personally and pay for the privilege over reliance on witnesses was a sign of desperation and extreme frustration is difficult to avoid. However, combat was an accepted means of adjudicating cases involving disputed property ownership in England during this time. See Robert Bartlett, Trial by Fire and Water: The Medieval Judicial Ordeal (Oxford: Clarendon Press, 1986), 108.

${ }^{130}$ Carpenter, The Minority of Henry III, 367.

${ }^{131}$ William Marshal, Earl of Pembroke, to Hubert de Burgh, Justiciar (no. LIX), Oct. 1219-March 1220, in Royal and Other Historical Letters, 71. For other, minor disputes involving William, see Curia Regis Rolls vol. 9, pgs. 79-80 and vol. 8, pgs. 208, 210.

${ }^{132}$ William Marshal, Earl of Pembroke, to Hubert de Burgh, Justiciar (no. CLII), April 1222, in Royal and Other Historical Letters, 175. Carpenter dates this letter to 1221. See The Minority of Henry III, 243-244.
} 
suffering financially as it sought to establish its authority after the rebellion, required that Marshal give up his control of the royal Exchange. In this instance he acquiesced to the royal request, adding that he had found his inheritance "to be so burdened by debt and bequests that it is not yet able to be self-sufficiently solvent," and for this reason he informed the king that it is "very grave for me to withdraw from the utility" of the Exchange. ${ }^{133}$

After continued negotiation, the crown was finally able to prise the castle of Fotheringay from Marshal's grasp in November 1220. Marshal had stalled long enough, however, to gain aid from the crown in the urgent matter of the invasion of his Welsh lands by Llewelyn, the prince of North Wales. Unfortunately for Marshal the aid took the form of supportive letters directed to his loyal men residing in Wales. Llewelyn was able to cause significant damage to the Marshal powerbase, installing his own men in the areas surrounding Pembroke, and it was not until 1223 that Marshal was able to muster sufficient military strength and resources to reverse Llewelyn's gains. ${ }^{134}$

The crown's own concern over the control of its property was one important reason why Hubert de Burgh moved to solidify an alliance with Marshal. The young earl had demonstrated a stubborn unwillingness to cede control of castles that the crown claimed and needed to secure its position. The need for an alliance was strikingly reinforced when, in the spring of 1223, Marshal moved into Wales in force and won back many of his former holdings from Llewelyn without royal support. Hubert acted quickly to demonstrate the government's goodwill with a gift of deer, and even chose one of

\footnotetext{
${ }^{133}$ William Marshal, Earl of Pembroke, to Henry III (no. LVIII), July 1219-July 1220, in Royal and Other Historical Letters, 70.

${ }^{134}$ Carpenter, The Minority of Henry III, 307.
} 
Marshal's own men as the royal agent in charge of taking possession of Cardigan and Carmarthen, which the king claimed. The royal claim to Caerleon, which had been asserted in 1222, was left alone. After Marshal's show of force the government was happy to assist him further in Wales. In fact, Hubert went in person to render military aid to Marshal, and upon their joint success Cardigan and Carmarthen were transferred into Marshal's control. ${ }^{135}$ But the issue of the Welsh holdings was resolved quickly and easily compared to other property problems. Marshal had been warned against strengthening the castle of Marlborough, which the crown also sought to reclaim, along with the castle of Ludgershall. Negotiation over the two castles was not progressing so long as Marshal had little to gain from giving them up, but Hubert was pursuing a solution with Marshal that was vastly different from the unadulterated demands that he leveled at others. ${ }^{136}$

Those others, including Ranulf, Earl of Chester; Falkes; and William, Count of Aumâle, threatened by Hubert's castle policy, decided to approach the king with their concerns over the consequences of Hubert's power, but the justiciar fled with the king to Gloucester, having convinced Henry—in Falkes's opinion—that Ranulf and his companions intended to capture him. ${ }^{137}$ Unable to reach the king, they went instead to capture the Tower of London but were thwarted when Hubert and the king arrived in force to stop them. ${ }^{138}$ Negotiations averted civil war for a time, but only the threat of

\footnotetext{
${ }^{135}$ Ibid., 307-308. Marshal senior had been granted custody of Cardigan and Carmarthen by King John. See ibid., 77. For Caerleon, see pgs. 77, 294, 308. For Hubert's participation and the grant of Cardigan and Carmarthen, see pgs. 314-316.

${ }^{136}$ Castles could not be fortified without royal consent. See Stacey, Politics, Policy, and Finance, 14.

${ }^{137}$ Carpenter, The Minority of Henry III, 318.

${ }^{138}$ Ibid., 319. The threat of violence was not entirely random. Marshal had reported to Hubert an account of Falkes's angry outburst the previous year in response to a royal letter ordering him to observe John Marshal's right to a wood which happened to lie in one of Falkes's sheriffdoms. According to Marshal, Falkes retorted to the messenger that "if he [John Marshal] should send thirty comparable letters of the lord
} 
excommunication wielded by the archbishop of Canterbury, Stephen Langton, induced the dissidents to surrender their castles and sheriffdoms. Langton also ordered Hubert and others of his party, including the earl of Salisbury, to surrender their castles in the interest of evenhandedness, but it soon became apparent that this was not being enforced where Hubert's allies were concerned. ${ }^{139}$

The crown's reasons for pursuing an agreement with Marshal were set down in a letter to the English representatives at the papal court. The letter set forth a lengthy justification for the proposed solution that reveals both the crown's weakness at this time, Marshal's significance, and the importance of ensuring his loyalty. Marshal was a potential threat to the stability of the kingdom, due both to his extensive holdings and his ability to pursue a marriage alliance detrimental to the king, and the letter illustrates that the crown was acutely aware of that. In return for the castles and some peace of mind, William would marry the king's sister Eleanor. As the letter reveals, King Henry considered this agreement to be highly favorable, whereas many of his barons did not. The marriage between an English subject and a sister of the king not only transgressed against tradition, but compensated one subject for a loss that others were simply forced to endure. Although lengthy, the king's letter is worth quoting in full:

king to him, he would certainly not have peace concerning the said wood...and he called all natural men of England traitors; and, lying, urged that they wanted and desired war, and that such great war will come to them that all England will be too tight for them." See William Marshal, Earl of Pembroke, to Hubert de Burgh, Justiciar (no. CXCVII) in Royal and Other Historical Letters, 222. Carpenter dates this letter to 1222. See Carpenter, The Minority of Henry III, 272.

Other known dissidents in 1223 included Brian de Lisle, chief justice of the forest; Gilbert de Clare, earl of Gloucester; John de Lacy, constable of Chester; Robert de Vieuxpont, sheriff of Cumberland; Engelard de Cigogné, custodian of Windsor and Odiham; Peter des Roches, bishop of Winchester; William de Cantilupe, the king's steward; and Peter de Maulay, a prominent castellan and sheriff. See ibid., 320.

${ }^{139}$ Ibid., 326-327. 
Because there are, perhaps, some who will suggest to the lord pope and cardinals that certain things were recently done by us concerning the counsel of our faithful men and magnates, wanting to pervert these things as if they would be greatly prejudicial to us, we, like more cautious men, to refute their artifices, are led to explain here the whole series of certain affairs in order that you should not be in the dark about those things which have surrounded you. Therefore you should know that, because Earl Marshal still held the castles of Marlborough and Ludgershall during the time of the embassy of the lord bishop of Norwich [Pandulf] and proposed to marry the sister of Count Robert of Dreux, and there were other magnates in England who strove to turn him away from us through wicked confederations, a treaty was made in the presence of the said legate [Pandulf] and our justiciar and certain other magnates concerning one of our sisters being given to him, because at that time a confederation with foreigners was feared if he married the sister of the Count of Dreux, lest England lie open to foreigners entering more freely, especially while Richard Marshal brother of that Marshal has all his own lands in Normandy, moreover because the malice of they who were striving to turn the heart of that man away from us was feared, moreover also because...the said castles of Marlborough and Ludgershall would be restored to us (because much was obtained by us in order that...other magnates would be more easily induced to return our castles similarly held). On account of the foregoing and the condition of our weak position and that of the whole kingdom, one of our sisters was granted to the said Marshal by the authority of the said legate and by the counsel of such great magnates, for the reason that the said Marshal gave his word about marrying her if it should be pleasing to us and the magnates of the kingdom, and our justiciar gave faith about granting her to the said Marshal if the magnates of the kingdom would consent. And the said legate and our justiciar and all others who were present faithfully promised that they would adhere with all due diligence to this. And thus the said castles were returned to the hands of the said legate so that, if the agreement is not completed before a fixed limit of time has elapsed, they may be restored to Marshal himself without difficulty. And also after awhile, when these things had been related to the other magnates and the Earl of Chester expressly, who at that time had returned from the Holy Land, the Earl himself endorsed this greatly and many others consented with no one opposing [it]. Afterwards, however, certain dissensions rose up and certain men renounced this, as it was later said by part of them in court, because we do not have a greater treasure than the marriage of ourself and our sisters, whence it would be expeditious to espouse our sisters [in such a way] that we may have a great alliance in foreign parts. And thus at that time that business remained unfinished. However seeing that the same Marshal recently obtained an apostolic mandate directed to 
the Lord of Canterbury and the Lord of Salisbury in order that they should either confirm him to be thoroughly freed from that obligation of faith or that contract to be confirmed, and the same Marshal forcefully demanded that one of those ways would be advanced, since he was in fact unwilling to put off marrying his wife further. And by this and other means, and thus at present it is feared lest the same Marshal who is of such great power in England as in Ireland would marry the sister of the said Count of Dreux or the daughter of the Duke of Brabant who was similarly offered to him, on account of these things which we laid out before can in no way be tolerated by us, or likewise the sister of the king of Scotland, where similarly there lies no small danger so much the more because of how much nearer Scotland is [than] Ireland and to the lands of the said Marshal, that confederation would be much more dangerous to us. And thinking seriously about both the power of Marshal and his faithful pledge which he extends to us and expends especially effectively around regions [of] Wales and our castles which Llewellyn prince of North Wales held and certainly Marshal seized the same by his own hands, and they would hardly have been liberated except through his power and diligence; and considering also the example of the former King of France Philip who married his own daughters, sisters, and nieces to the Count of Lemur and the Count of Ponthieu and to his other men more willingly than to far-off foreigners, just as the king of France who now is recently united in marriage his niece, namely the daughter of Guischard de Beaujeu to the Count of Champagne, on account of the aforesaid things and the great matters which are hoped for concerning the said Marshal, it did not occur to us in the presence of all of these important men that we would marry our sister except to advance ourself and our honor, we from such counsel have considered beyond this careful treaty, without diminution of our lands, castles, or money, to grant our younger sister to him. ${ }^{140}$

The letter is dated April 1224, the same month that Marshal and Eleanor were married, and indicates that resistance and insecurity surrounding the alliance lasted up until the last minute. ${ }^{141}$ Indeed, two years earlier Marshal had written to Pope Honorius III in order to secure some form of closure on the matter. According to the papal account of William's request for assistance, Marshal had informed the pope that both Pandulf and Hubert de Burgh, "fully and firmly wishing to bind him to royal service anxiously and

\footnotetext{
${ }^{140}$ No. 140, Diplomatic Documents Preserved in the Public Record Office: Volume 1, 1101-1272, ed. Pierre Chaplais (London: H. M. Stationary Office, 1964), 95-97.

${ }^{141}$ They were married on April 23. See Carpenter, The Minority of Henry III, 354.
} 
diligently induced the same to marry one of the sisters of our dearest son in Christ, the illustrious king of the English, certainly to the advantage of the king himself, upon which, by the counsel of many bishops, counts, and barons who were then present in the kingdom he was advanced to such a degree that many noblewomen were laid aside who had been offered to him and he swore to marry one of the sisters of the aforementioned king." However, the impending marriage continued to be frustrated. The same account recorded that "because indeed certain jealous persons have presumed to hinder this, not caring how much benefit to king and kingdom is hoped [for] from this, but only desiring to cause injury," Marshal was led to request "that it might be observed more firmly," and asked that "we should mandate that what was confirmed by oath should be fulfilled." The pope charged the archbishop of Canterbury and the bishop of Salisbury with fulfilling the marriage agreement. ${ }^{142}$

The nature of the objections over the marriage of Marshal and Eleanor are unknown beyond what is mentioned in the above royal and papal letters. The papal letter directed to the two bishops indicates that Marshal's social advancement from powerful subject to member of the royal family was one probable, and significant, source of tension. Marshal was so advanced, according to the letter, that he "laid aside" the noblewomen who could have made a fitting match for him and instead pursued a royal match. The one reason provided for the hindrance of the marriage was jealousy. The

\footnotetext{
${ }^{142}$ Pope Honorius III to the Archbishop of Canterbury and the Bishop of Salisbury, June 16, 1222 (16 kalends July), Registers of Pope Honorius III, vol. 11. fol. 258, microfilm, Institute of Historical Research, London. For a short summary of this document in English and the full date, see Calendar of Entries in the Papal Registers Relating to Great Britain and Ireland: Papal Letters, A.D. 1198-1304, ed. William Henry Bliss (London: H. M. S. O., 1893), 1:88. It should be noted that Carpenter misrepresents this letter as being Marshal's own words. See The Minority of Henry III, 244.
} 
royal letter, on the other hand, says simply that the main objection was that Henry should marry his sisters to men outside of England in order to create foreign alliances. These two objections, which may at first appear to lack any cohesion, become intertwined when viewed from the perspective of royal marriage practices in England since the reign of William I.

Henry's wish to marry his sister to Marshal made sense on a practical level. His government was actively trying to regain control of royal strongholds, and Marshal held two that he wanted to reclaim. The earl was a great landholder with powerbases held directly or within the family that nearly surrounded England. Henry had every reason to maintain a close alliance with him, and accomplishing this through marriage was an obvious option. But Marshal's marriage to Eleanor was in fact unprecedented. No English king descended from William the Conqueror had ever married one of his sisters or daughters to one of his English subjects. Instead, marriages had been contracted with foreign powers. One nineteenth-century historian noted that Henry "thought it necessary to apologise for consenting to such a match," explaining the tone of justification which runs throughout his letter. ${ }^{143}$ In particular, Henry's evocation of the example of King Philip's marriage politics is indicative of the unusual situation he found himself in. For the first time, an English king descended from William the Conqueror found that his position in relation to the aristocracy of England mirrored that of the king of France.

When the Duke of Normandy conquered England in 1066, he seized the opportunity to institute a system whereby his followers would be rewarded with land

\footnotetext{
${ }^{143}$ Tewars, "Marriages of English Princesses," Notes and Queries: A Medium of Intercommunication for Literary Men, General Readers, Etc. 7 (1871): 203.
} 
tenure in return for military service. However, William retained the right to the land, making him the sole landowner in England. ${ }^{144}$ As the only true claimant to English soil, the king had little reason to craft marriage alliances with his English subjects. In France, the royal powerbase was limited geographically and the influence of the king was defied by highly independent barons who held competing ties of vassalage and longstanding traditions of autonomy. ${ }^{145}$ Contracting marriages with subjects was a prime strategy of the Capetian house to gain alliances, stability, and more direct influence in the lands outside the royal demesne, a point to which King Henry alluded in his letter. Up until the First Barons' War, the king of England had never had to contend with the degree of dissension within England experienced regularly by the king of France on the Continent. ${ }^{146}$ The rebellion changed the king's relationship with his barons and created a context wherein the marriage between a powerful subject and a member of the royal family was highly favorable to the king, but not necessarily favorable to his other subjects. The match ran against all precedent in England and raised one member of the baronage above any ordinary expectation, likely prompting the claim of jealousy

\footnotetext{
${ }^{144}$ David C. Douglas, William the Conqueror: The Norman Impact upon England (Berkeley: University of California Press, 1964), 273.

${ }^{145}$ For the autonomy of territories in France, see Jim Bradbury, Philip Augustus: King of France, 1180 1223 (London: Longman, 1998), 5-7. Some lords, like the count of Flanders, actually held lands within their county from the king of France and the emperor of Germany, a situation which resembled that of the elder Marshal after he paid homage to King Philip for his Norman lands. For Flanders see John W. Baldwin, The Government of Philip Augustus: Foundations of French Royal Power in the Middle Ages (Berkeley: University of California Press, 1986), 8. For Capetian marriage practices, especially during the reign of Philip Augustus, see ibid., 269-272.

${ }^{146}$ The civil war between King Stephen and Empress Matilda is not considered here because the conflict was over their rival claims to the English throne and not with members of the baronage specifically.
} 
recorded in the papal letter and Henry's admission that his barons urged him to pursue a (traditionally acceptable) foreign alliance. ${ }^{147}$

The negotiations with Marshal had a happy ending, and King Henry’s new alliance with him proved even more useful than anticipated. Just nine days after his marriage Marshal was appointed justiciar of Ireland and charged with subduing Hugh de Lacy, a mission which ended in triumph. ${ }^{148}$ However, 1224 was a tragic year for those who could not come to terms with the crown, as represented by Hubert de Burgh. The dissidents had agreed to a peace with Hubert and had even been given back some of their properties, but Falkes was unable to participate in the amnesty for long. He was charged with breach of the peace, a charge which is difficult to explain and which he himself said pertained to something he had purportedly done several years before. David Carpenter has suggested that Marshal was probably one of the instigators of the charge, since he was one of three men who stood to gain property from Falkes if he was convicted and he was at Hubert's right hand because of his marriage and his appointment to the justiciarship of Ireland. The consequences for Falkes could be dire: if he did not appear to

\footnotetext{
${ }^{147}$ For the English baronage, marriage was an important means of maintaining cohesion and identity. Scott Waugh has observed that the agreement to seek baronial consent in the marriages of heiresses was a feature of the coronation charter of Henry III, and that throughout Henry's reign, the choices he made concerning the marriages of his own family members and members of the baronage caused great consternation among the barons. The barons were threatened by Henry's tendency to make decisions without consulting them. In his letter to the papal court, Henry was very concerned to explain that his barons had initially consented to the match between Marshal and Eleanor. According to Waugh, Marshal's marriage to Eleanor was the first example during Henry's reign when the issue of consultation became contentious. Waugh does not discuss the specific concerns of the barons in this instance, however. It should also be noted that he incorrectly names Richard Marshal as Eleanor's intended husband. See Scott L. Waugh, "Marriage, Class, and Royal Lordship in England under Henry III," Viator 16 (1985): 198-199, and 199, n. 49.

${ }^{148}$ For Marshal's appointment as justiciar, see Carpenter, The Minority of Henry III, 355. For Hugh de Lacy's invasion, see pg. 306. Hugh had invaded Ireland in order to take back lands which he had held as earl of Ulster before he was disseized by King John.
} 
answer the charges, he would be outlawed, and if he was convicted, capital punishment was a distinct possibility. ${ }^{149}$

Rather than comply with the government's wishes, Falkes fortified two of his castles, one of which, Bedford, was under the control of his brother William. Meanwhile Falkes was convicted of several disseisins by a court headed by Henry of Braybrooke, who was no friend of Falkes's family, and William de Bréauté captured Braybrooke in retaliation. When the government's order to release the justice was ignored, royal forces besieged Bedford. In order to prevent any of Falkes's former fellow dissidents from coming to his aid during the eight-week siege, the government began dispensing concessions. The siege concluded with the surrender of William de Bréauté and his garrison, and then, finally, the hanging of more than eighty members of the garrison, including William. Since he was not present in the castle during the siege and had indicated his willingness to surrender before it fell, Falkes was absolved, resigned all of his properties, and left for the Continent. Shortly thereafter Marshal got four manors back. $^{150}$

During the siege of Bedford and Marshal's absence in Ireland, King Louis (Philip Augustus had died in 1223) was gaining Plantagenet lands. Poitou had fallen to his forces and Gascony was in his sights. King Henry responded by sending his brother Richard, earl of Cornwall, to the Continent with an army and plenty of funds. In order to avoid the resistance that King John had suffered surrounding foreign military service, Hubert argued that a tax was needed regardless of the situation on the Continent, because Louis

\footnotetext{
${ }^{149}$ Ibid., 351-353.

${ }^{150}$ Ibid., 356, 360-367.
} 
was threatening to invade England again. Therefore, funds were needed for the defense of the realm, which of course concerned all English barons. The tax and the need to render assistance on the Continent went over smoothly, ${ }^{151}$ and as late as 1230 Marshal was assisting the king in his campaigns on the Continent. ${ }^{152}$

Between the years 1226 and 1231, when Marshal died, the surviving sources and modern histories have almost nothing to say about him. His relationship with the crown, and Hubert in particular, became strained. Like the dissidents who had become alarmed by Hubert's power in the years 1223 and 1224, Marshal also came to distrust Hubert. The justiciar had become so entwined with the crown and its wellbeing that his interests seemed inseparable from those of the king. His power in Wales continued to increase, and his nephew replaced Marshal as justiciar of Ireland in 1226. In 1227 Marshal lent support to Richard of Cornwall's "military demonstration" against the king and Hubert, a dispute that centered on a manor held by Richard being given to Hubert's nephew. The dispute brought Marshal together with former opponents, including the earl of Chester, to proffer war to the king. Although King Henry was able to settle the problem with his brother Richard, Marshal found the alliance with Richard to be worth maintaining, and shortly before his death he married his sister Isabella to him. ${ }^{153}$

Over the course of the years 1215 through 1231, Marshal's career closely resembled those of other contemporary barons. He navigated between positions of loyalty and disloyalty while striving to maintain his rights and properties. The instability of the

\footnotetext{
${ }^{151}$ Ibid., 379.

152 Powicke, The Thirteenth Century, 1216-1307, 95.

${ }^{153}$ For Richard's demonstration, see David Carpenter, The Reign of Henry III (London: Hambledon Press, 1996), 48; and Vincent, Peter des Roches, 265-266. For Richard's marriage, see ibid.
} 
government and the factions led by Hubert de Burgh and Peter des Roches created, or helped continue, conflict not only between king and barons, but among members of the baronage. An environment of intense competition and uncertainty led to the fall of subjects perceived as over-mighty by their peers, such as Falkes de Bréauté, and eventually Hubert de Burgh. ${ }^{154}$ Marshal was atypical in one respect, and that was his marriage into the royal family facilitated by his alliance with Hubert. The unprecedented match between a subject and a king's sister met with a great deal of resistance, explained in the sources only as jealousy and the preference of the barons for their king to marry his sisters in order to forge foreign alliances. These wide-ranging concerns are reflected in the History, which asserts the elder Marshal's loyalty and represents him as a humble yet effective royal servant whose power was supported by his contemporaries. The History justifies Marshal's prominence and by extension that of his son, bolstering young Marshal's own political position as he was under attack for his impending alliance with the royal house.

\footnotetext{
${ }^{154}$ Hubert de Burgh fell in 1232. His enemies from the 1220s, including Peter des Roches and Ranulf of Chester, were involved in his downfall. The most damning attack directed at the justiciar accused him of inciting riots against clerks sent to England by the pope. Peter had been appointed by the pope to investigate the riots. See David Carpenter, "The Fall of Hubert de Burgh," Journal of British Studies 19 (1980): 11-13.
} 
Chapter Three:

The History and the Earl

As a work of history the History of William Marshal is highly problematic. Its distance from the events which it discusses ranges from a span of only a few years to several decades. Although the poet makes references to written sources-tallies of tournament victories, for instance-he must have relied a great deal on his imagination to reconstruct the past. At the time he was writing, the early years of the elder Marshal's life had passed beyond the recall of living memory, and he must have utilized family stories and whatever written sources were available. The amount of dialogue present in the History indicates that the poet drew from sources both written and oral to create a history of Marshal that he felt to be reflective of an inaccessible past. Although John the poet was a self-conscious historian, his work was ultimately free from strict dependence on anything that could be considered a precedent. He does not cite other historical works, although he must have had access to them because he includes a great deal of historical context. If the History had been composed as a chronicle account of Marshal's life by an individual who was Marshal's generational contemporary, the problems would have been slightly reduced, but we do not have the benefit of a generationally contemporary and detached observer. Many things, mostly larger historical events, can be verified by outside sources, but as the story of an individual, the History is substantially unverifiable. The crucial and most fascinating aspects of the History are linked to the identity of the protagonist (both how he saw himself and how others saw him). While the historical records pertaining to Marshal's life certainly have a great deal to say about how he was 
regarded by his patrons, and something to say about how he regarded himself, they cannot provide the same type of details that the History presents, or verify them. The History compounds the limitations of any history with the intricacies of its own context, which poses a challenge to anyone trying to interpret its contents.

The intent behind the History is difficult to comprehend fully. Ultimately, the work was outlined and constructed entirely without the input of its protagonist, so its goals, intentions, and perspectives cannot be said to be those of the first earl of Pembroke. If the aim was to construct an image that he would have recognized and agreed with, it was still an image shaped by the interpretations of those who contributed to the work. The choice of what to include and what to exclude was dictated by available sources and the desires of the patron. Those desires could have included the wish to memorialize, celebrate, or defend the subject, but all of those concerns were secondary to deeper motivations. Something prompted the second earl of Pembroke to commission a work that is a memorial, a celebration, and a defense of his father, and, most importantly, a justification and explanation of Marshal family power.

David Crouch is the only historian to have examined the History from the perspective of its purpose in a substantial manner. He has recognized that the History can accurately be called a defense and that it was propaganda promulgated by young Marshal. Many of his ideas are insightful, but they lack contextual parameters. Crouch answers the question of why a defense of the elder Marshal was mounted by pointing to negative opinions of Marshal current in his own lifetime and after his death. As will be seen, this concept, while not inaccurate, needs to be complicated. Furthermore, Crouch does not 
address the crucial question of why young Marshal personally found a defense of his father necessary. He acknowledges that the History "was unique in its generation," but adds that the reason that it "took the shape it did cannot I think be due to anything other than the eccentricity of its patron, and the innate historical talent of its author."155 This chapter will provide a more satisfying explanation of the motivations behind the History and to whom its defensive aspects were likely directed.

The details of the young Marshal's life that can be reconstructed up to the year 1226, when the History was likely completed, constitute the context for the commissioning and writing of the work. As was seen in the previous chapter, Marshal was singular among the barons only due to the nature of his alliance with the government. His proposed marriage and the unusual circumstances of the alliance made him the focus of attention and debate within England, as indicated by the resistance to the marriage. The opening lines of the History reveal that the work was written is response to current issues. John the poet asserted that "there are those who, though having little understanding, / make a habit of going on the attack, / bent on denying that what is good is so. / And where does this habit of theirs come from? / From envy. A man who, out of deep-seated bitterness, / cannot hold his tongue, will not be pleased, / either, with good things, however great." ${ }^{, 156}$ The reference to envy echoes the claim of jealousy recorded in the papal response to Marshal's plea to the pope about his marriage. Although the reference in the History is ambiguous, it indicates that Marshal was facing pressure about something that he felt a history of his father would address.

\footnotetext{
${ }^{155}$ Crouch, "Biography as Propaganda," 506.

${ }^{156}$ History of William Marshal, 1:3.
} 
In regard to the concept of a posthumous defense, Crouch has written of the History that "a very big theme of the author is the unimpeachable loyalty and faithfulness of his hero-often doubted, ever vindicated — and this preoccupation tells us quite clearly that it was precisely that loyalty and faithfulness which was being impeached in the 1220s." ${ }^{\text {157 }}$ The only three sources that Crouch draws from in his article are the History itself—which does address certain accusations explicitly—Matthew Paris's chronicle, and a letter in Philip Augustus's Norman cartulary. The first is the better of the three sources, since it is at least contemporary to the young Marshal. Paris's chronicle was not begun until 1235 , sixteen years after the death of Marshal senior and nearly a full decade after the History was completed. Crouch has cited a comment made by Henry III to Walter Marshal, $5^{\text {th }}$ earl of Pembroke, which Paris recorded in his chronicle in 1241, as evidence that the patriarch of the family was viewed as a traitor, at least in later years. But the comment is part of a longer dialogue that places it squarely within the context of the year it is said to have been made. The whole anecdote recalls that Henry would not allow Walter to claim his inheritance upon his brother Gilbert's death. According to Paris, the king angrily addressed Walter:

Your father William is tainted with treachery, for he is said to have saved Louis from being taken when in England; your brother Richard was taken prisoner and slain in arms against me as an open and deadly enemy; and your brother Gilbert, lately deceased, to whom, at the instance of Edmund, archbishop of Canterbury, I granted his inheritance, more as a favour than as his right, unluckily instituted a tournament at Hertford, in spite of my prohibition, at which he met with a miserable death. And you too, Walter, who, against my wish, and notwithstanding my prohibition, and in contempt of me, were present at that tournament, and sophistically termed

\footnotetext{
${ }^{157}$ Crouch, "Biography as Propaganda," 505.
} 
it a venture-on what grounds do you demand your inheritance, and how have you the effrontery to do so? ${ }^{158}$

Henry's comment about Marshal's treachery appears in the context of the king's full complaint as one item in a list of grievances against the Marshal family. Looking back from the year 1241, the king must have been suspicious of the family, and more recent events would certainly have colored the past. However it appears odd that the king, doubtlessly apprised of every aspect of his government's relationship with the French king, distanced himself from the charge of treachery leveled against the senior Marshal by claiming ambiguously that "he is said" to have dealt too leniently with Louis. The qualification suggests that, if at all accurate, the negative opinion of Marshal was held not by the king himself but by unidentified others. Or, at the very least, the king was unable or unwilling to charge the senior Marshal directly. In his 2002 biography of Marshal, Crouch comments that "it is likely that Matthew was recording a genuine feeling of disenchantment later current in royal circles about the Marshal's doings at this time."159 This accurate assessment of the relevance of Paris's anecdote also indicates why it should not be included in a discussion of Marshal's reputation in the 1220s. Paris's chronicle, and certainly this anecdote, cannot be taken as evidence that Marshal's reputation remained consistent from the 1220 s to the 1240 s.

Finding evidence of something as subjective as an individual's reputation during this time comes with great difficulty and endless qualifications. Roger of Wendover was the only English chronicler writing during the period ranging from the elder Marshal's

\footnotetext{
${ }^{158}$ Matthew Paris, English History from the Year 1235 to 1273, trans. J. A. Giles (New York: AMS Press, 1968), 1:378.

${ }^{159}$ Crouch, William Marshal, 135.
} 
death through the career and death of William junior. Matthew Paris continued Roger's work from the year 1235 and even added some material to the previous years, but Roger remains the only contemporary narrative source for the period in question. As opposed to Paris's inclusion of often unflattering Marshal anecdotes, Roger recorded that the deaths of William senior and William junior were much lamented. He included a highly favorable epitaph about William senior that described him as "obnoxious to the Irish on account of subduing them; he was the honour and glory of England; a trader with the Normans, for he purchased many places in that country; and to the French he was warlike and invincible." Young William, according to Roger, was a "bold knight" who "closed his life lamented by many." ${ }^{160}$ Although David Crouch's use of Paris's chronicle is sparing, the inclusion of Paris in any discussion of the Marshals during the 1220s and preceding years should be avoided. His generally negative opinion of the Marshals can easily be countered by Roger's more favorable, and contemporary, view. ${ }^{161}$

The evidence provided by the Norman cartulary is equally problematic. Crouch cites a letter sent by young Marshal to King Philip as evidence of the ongoing need to defend the elder Marshal's homage to the French king for his Norman lands. He interprets young Marshal's reference to letters of King John given in apparent support of his father's homage to King Philip as evidence that he was defending his father. ${ }^{162}$ The History claims only that Marshal senior had verbal permission from King John to pay

\footnotetext{
${ }^{160}$ For Marshal senior's epitaph, see Wendover, Flowers of History, 2:413-414. For Marshal junior, see pg. 539. Other significant sources for the period like the Annales Monastici provide little beyond a chronological record of events.

${ }^{161}$ Other historians who have written about Marshal and the First Barons' War have commented on the problems of using Paris as a source. In particular, Paris was a partisan of Hubert de Burgh, whose alliance with young Marshal had dissolved in the last years of the 1220s, as was seen in the previous chapter. See Painter, William Marshal, 221, 225-226; and Norgate, The Minority of Henry III, 48, n. 6; and 49, n. 7. ${ }^{162}$ See Crouch, "Biography as Propaganda," 505-506.
} 
homage to the French king. ${ }^{163}$ Marshal's letter to King Philip does not just claim that his father had letters, however. In it, Marshal also asserts that he too has letters. He wrote that, should his brother Richard die without heirs, "I should pay liege homage to the lord king of the Franks for the same [land] on this side of the sea and whatever I should, [in] the same manner and in the same condition as the aforesaid William, my father, paid homage to him, namely bringing for them [the lands] the letters of the king of England, just as my father did."164 If the elder Marshal's homage remained controversial, it does not stand to reason that young Marshal would pursue the same agreement with the French king. Nor does it follow that letters from the king of England would be attainable or valid. In addition to this evidence, Roger of Wendover's epitaph of Marshal, cited previously, also included a favorable judgment concerning Marshal's ownership of Norman lands.

One of the most significant problems with the use of Paris's anecdote and the Norman cartulary as evidence that the first earl of Pembroke's reputation went downhill after his death is that both sources are royal, whether directly in the case of the cartulary

\footnotetext{
${ }^{163}$ See History of William Marshal, 2:149.

${ }^{164}$ See no. 285 in Cartulaire Normand de Philippe-Auguste, Louis VIII, Saint-Louis et Philippe-le-Hardi, ed. Léopold Delisle (1882; repr., Genève: Mégariotis Reprints, 1978), 43. The whole letter reads, "I William Marshal, earl of Pembroke, make known to all that, by my wish, I have granted and quitclaimed to my younger brother Richard all the land which William Marshal, my father, held and possessed in Normandy on the day that he died, and I have asked lord Philip, the illustrious king of the Franks, that the same Richard, my brother, should receive as his liegeman all of that land in such a manner that if the same Richard should die without an heir from his betrothed wife, that land should return to me, and I should pay liege homage to the lord king of the Franks for the same [land] on this side of the sea and whatever I should, [in] the same manner and in the same condition as the aforesaid William, my father, paid homage to him, namely bringing for them [the lands] the letters of the king of England, just as my father did, and returning whatever feudal relief the land owed, in the usage and customs of Normandy. If that land should return to me, however, I shall swear to the lord king of the Franks that I should either restore to him the fortifications of the whole land aforementioned to strength, great and small, as often as I am asked concerning this either by him or by his authentic command. So that this should be firm and stable I have caused the present letter to be composed and strengthened by the placement of my seal."
} 
or by presumption, in the case of Paris. Royal disfavor of the young William at the French court is credible, given the circumstances of his abandonment of Louis during the First Barons' War, but not particularly relevant in England. On the other hand, even if Paris's anecdote recorded a real conversation between Henry III and Walter Marshal (or served only as an encapsulation of contemporary sentiment), it is still unsustainable as a piece of evidence because of its distance from the events of the 1220s and the fact that it simply does not match the tone of the government's relationship with the young Marshal during that decade. The government was, after all, deeply concerned with forging a strong relationship with the young Marshal, as Henry's letter forthrightly explains, and Hubert de Burgh's actions demonstrate. Furthermore, the alliance with Marshal could not be taken for granted, and it seems highly doubtful that the government would antagonize its potential ally by disparaging his father's memory. Finally, the introductory lines of the History reference envy-driven attacks, making the connection between any potentially negative opinions held by the king or his main policymakers to William's reasons for commissioning the History implausible in the extreme. The charge of envy instead points to Marshal's peers, and specifically those who were not engaged in an alliance with him.

One contingent with motivation to disparage the senior Marshal and question his loyalty was the faction headed by Bishop Peter des Roches. Peter became increasingly estranged from the government as Hubert de Burgh's power grew. The bishop had no role in the alliance Hubert was forging with Marshal, and negotiations began when he was out of the country. ${ }^{165}$ As was discussed in the previous chapter, Peter eventually opposed Hubert openly over the policy of royal castle resumption, and aside from Hubert

\footnotetext{
${ }^{165}$ Carpenter, The Minority of Henry III, 239.
} 
himself, Marshal was the figurehead of this policy. After all, the king himself wrote that it was hoped that Marshal's example would lead other barons to acquiesce to the government's demands. Peter and his faction would undoubtedly have fought to stop the alliance between Marshal and Hubert from getting stronger. Since Hubert was the main governmental policymaker at the time, Marshal marrying into the royal house would have meant exactly that. Both Peter and Hubert owed their positions within the government to their loyalty to King John and their espousal of the royalist cause. Marshal, however, could be attacked not only for his own rebellion, but for any perceived disloyalty of his father, because he owed his strong position to the gains his father had made in royal service. ${ }^{166}$ It is not impossible to imagine that Peter, and likely the other barons of his faction, such as the earl of Chester, could not countenance a former rebel being elevated through marriage into the royal family. Indeed, whether ex-rebel or royalist, attacking the first earl of Pembroke's loyalty would have served as an expedient means of undermining the son. This explanation also compliments the evidence provided both by the papal letter and the History itself, which speak of envious individuals and attacks. An accusation of envy directed at the baronial malcontents of the 1220 s is plausible, whereas mainstream governmental disparagement of the elder Marshal is not.

In Crouch's view, the senior Marshal's allegiance to King John was one of the most significant factors contributing to the damage of his reputation. He asserts that "it was very unfortunate for the Marshal's reputation that he had been so very close to John,

\footnotetext{
${ }^{166}$ Crouch makes a similar observation. He has written that "the issue of loyalty is always the key to his [Marshal's] biographer's concerns. As a knight in the household of the Young Henry, the Marshal's léauté and féalté were the reasons why he was employed and employable. It was also the issue by which his enemies attacked him." See "Biography as Propaganda," 508.
} 
both as count of Mortain and as king. Everyone knew it, but it brought the Marshal no credit in the generation that followed, which despised John as a tyrant and a cataclysmic failure as king." ${ }^{167}$ However, Marshal was far from alone in his loyalty to John. Many of the most important figures of the early years of Henry III's reign were holdovers from John's, including, as has been noted, Hubert de Burgh, Peter des Roches, Ranulf of Chester, and Falkes de Bréauté. Regardless of their relationship with, or position within, the government of Henry III, fidelity to John was a shared feature of their pasts. Thus, justifying the senior Marshal's close relationship with King John to many of the leading barons of the 1220 s would not have been necessary.

The treatment that King John receives in the History cannot be dismissed so simply, however, in large part because it is a work that was commissioned and funded by a man who not only fought opposite his father in the war against King John, but whose loyalties continued to be conflicted throughout his career. During the majority of the 1220s young Marshal was involved in forging a strong relationship with the new king, but as has been seen, this relationship did not preclude future rebellious behavior. Whereas the elder Marshal's later career was defined by his loyalty to King John, the beginning of young Marshal's career was defined by his disloyalty to the king. The narrative of the History is a product of these complicated factors. Its treatment of the elder Marshal's relationship with King John cannot be interpreted uncritically as an attempt to distance Marshal from him in light of contemporary criticisms. Young Marshal's most important political relationships were being forged with royalists in the 1220s. However, young Marshal had absolutely no reason to laud King John and it is

${ }^{167}$ Crouch, "Biography as Propaganda," 506. 
abundantly clear that many of the memories of John that informed the History were negative. Where the memories came from, and whether they are accurate or fabrications are difficult factors to determine, but they were certainly interpreted by the patron of the work. $^{168}$

In particular, Crouch views the History as being "a defence of the Marshal from charges of being too close to King John, of being his henchman rather than his victim."169 This is problematic again in respect to young Marshal's dealings in the 1220s, but also because the elder Marshal himself was suspected of disloyalty by John at certain points in time. His homage to King Philip and the refuge he provided for William de Briouze, both of which resulted in hostage-taking, were episodes that, whether intentionally or not, initially placed him in opposition to King John. Marshal's contemporaries would have been very aware of these scandals. The History is in fact concerned to demonstrate that these actions were done with no harm in mind, and in the first instance, with full permission. Crouch adds that the History argues that Marshal was a loyal man victimized by King John. But King John also affirms Marshal's worth in the History. In fact, on his deathbed, the king becomes one of Marshal's strongest advocates, saying that "I place my trust in him / as regards loyal service more than in any other man," and then proceeds to grant Marshal custody of his son and permission to help the child govern England. ${ }^{170}$ What could possibly make Marshal more close to John than being handpicked to guard his son and govern for him? This scene is a strong example of the justification, and

\footnotetext{
${ }^{168}$ David Crouch does not go so far as to impart any particular viewpoints to young Marshal. Instead, he comments that the poet "loathed King John." See William Marshal, 11. However, it is more likely that the poet was expressing the views of his patron, regardless of his own opinions.

169 Crouch, "Biography as Propaganda," 511.

${ }^{170}$ History of William Marshal, 2:261.
} 
explanation, of the Marshal family power that runs throughout the History. Both the royal and papal letters asserted that an alliance with young Marshal was highly beneficial to the king, a stance which the History propounds concerning the elder Marshal's relationship to all of his royal patrons, and especially King John.

Concerning the scene of John granting custody of his son, Crouch notes the distinct possibility that King John did not entrust Marshal specifically with those duties, since his testament orders a council of thirteen barons to aid his sons. ${ }^{171}$ Regardless of the likely reality, the History is making a strong case for the value of the Marshal family's service to the crown. In the History, the power of the Marshal bolsters and supports the king. Young Marshal needed to portray his father in this way, and himself, in order to assuage the concerns and nullify the attacks of contemporaries displeased with his marriage and his acquisition of yet more influence. Yet Marshal's relationship with John in the History is complicated, further revealing the complex position of young Marshal. In the end it must be said that the History walks a fine line. Marshal senior is not disassociated from the king, since John is both an antagonist and advocate. The king receives criticism at the same time that he is depicted as an agent of legitimization for Marshal.

There are two anecdotes in particular that could be interpreted as blatant attempts to separate Marshal from King John, but the effect is so jarring that they likely represent young Marshal's viewpoints placed in the mouth of his father. Both anecdotes unintentionally cast doubt on the elder Marshal's ethic of loyalty, which is problematic because loyalty is the most important theme in the History, and the poet constantly

${ }^{171}$ Crouch, William Marshal, 124. 
reminds the reader of how loyal his protagonist was. In the History, Marshal's loyalty is a loyalty of support. He acts rightly and always does what his patrons need and request, but there are two major instances when Marshal's words cannot be reconciled with his actions. The first occurs during a scene when King John is attempting to put Marshal on trial for his homage to King Philip. After arguing his loyalty and submitting to the king's wishes, Marshal addressed the assembled barons. He proclaimed, "My lords, look at me, / for, by the faith I owe you, / I am for you all this day / an exemplar and model. / Be on your alert against the King: / what he thinks to do with me / he will do to each and every one of you, or even more, / if he gets the upper hand over you." ${ }^{\prime 12}$ This is a shocking declaration of opposition that the History places in Marshal's mouth, made even more so by the presence of the king, whose reaction is ineffectual anger. Crouch asserts that the History makes this fight appear worse than it actually was in order to "persuade the reader that the Marshal was a hero of the moral resistance to the ogre-king." But, as Crouch also notes, this was far from the truth. ${ }^{173}$ No contemporary would have been convinced. Instead, the sentiment expressed in the anecdote falls in line with baronial views of seigniorial abuse certainly held by young Marshal. It is also a setup for the stance that the History eventually takes on the First Barons' War: namely that some rebels were justified in their actions.

The next episode occurs near the end of Marshal's life. On his deathbed, he tells young king Henry that, "if it were the case that you followed in the footsteps / of some wicked ancestor, / and that your wish was to be like him, / then I pray to God, the son of

\footnotetext{
${ }^{172}$ History of William Marshal, 2:159.

${ }^{173}$ Crouch, William Marshal, 98.
} 
Mary, / that He does not give you long to live / and that you die before it comes to that." ${ }^{, 174}$ This speech is particularly problematic not only because it borders on treason but because it throws Marshal's whole ethic of loyalty into question. It boldly indicates that Marshal would rather the king die than resemble the man to whom he had been so loyal, and whom he had supported with his life, limbs, and resources. The ramifications of Marshal's loyalty are left open to speculation. The words spoken by Marshal in the History could be an accurate reflection of his sentiments towards the end of his life, and an attempt by the author to complicate Marshal in a historically realistic fashion.

However, this interpretation is doubtful because both anecdotes discount the real reasons behind Marshal's actions, and the complex rationale behind his choice to remain loyal. Both anecdotes are best interpreted as the opinions of young Marshal, whose interests were served by the view that the First Barons' War was a justifiable rebellion and that a king resembling John would not be tolerated in the future. Furthermore, it cannot be said with certainty whether anecdotes like the preceding two were meant to create distance between King John and Marshal as a defense, or whether young Marshal genuinely thought that his father had been victimized by the king. The latter is more likely, especially since he asserted in his letter to King Philip that both he and his father had letters of the king of England, making their homage for their lands in Normandy legitimate, and John's anger unreasonable. Regardless of the accuracy of the depiction, Marshal's words in these anecdotes are an excellent example of how difficult the History is to interpret.

\footnotetext{
${ }^{174}$ History of William Marshal, 2:407.
} 
The character of King John serves as a foil in the History. Marshal senior stood out from so many of his contemporaries because of his rise from younger son of a minor baron to regent of England. His great success was achieved solely through loyalty to the royal house, and the History is determined to depict him as relentlessly loyal, as has been noted by Crouch. But it is more than just loyalty that the History emphasizes-it is his role as a royal servant who suffers and prospers in accordance with the royal will, and does nothing to overshadow or harm his patrons. King John is an unappealing character in the biography, and he represents the opposite of William Marshal. The History charges John with "abiding pride.../ which was always the cause of his downfall." ${ }^{, 175}$ It claims that "day by day the King's arrogance grew / and grew, a fault which does not allow those in its grip / to see reason but brings them down." ${ }^{176}$ The insistence on John's arrogance and the downward spiral that it created places him on an opposing trajectory to Marshal, whose relative humility, good sense, and loyalty raise him to the uppermost heights of the kingdom.

For Crouch, the History "was devised to answer inconvenient criticisms of the old Marshal current in the 1220s. It argues that for all the accusations of self-serving, he was a scrupulously correct and-above all-a loyal man." ${ }^{177}$ The point is an accurate one. No matter the perspective, royalist or ex-rebel, Marshal could easily be attacked as selfserving. Perhaps for this reason, loyalty and humility are inextricably linked in the History. The influence and power wielded by Marshal is diffused through a coterie of outspoken supporters who advise and advocate for him, serving to justify and explain his

\footnotetext{
${ }^{175}$ Ibid., 107.

${ }^{176}$ Ibid., 127.

${ }^{177}$ Crouch, "Biography as Propaganda," 511.
} 
rise to power. When there is an important decision to be made or he is under threat, Marshal is never alone. In this way, his power appears to be the result of outside support as opposed to self-serving initiative. The advisory council vignette is employed repeatedly to create an aura of unanimity and to represent Marshal as a thoughtfully humble man, whether the councilors consist of anonymous barons or named individuals, and is echoed by King Henry's letter to the papal court explaining that the marriage alliance with young Marshal was supported by the barons.

Although nearly 40 percent of the lines of the History are dedicated to John's reign and the subsequent period of Marshal's regency and death, Marshal's character attributes of humility and loyalty are present within the History from the beginning. The theme of testing and suffering, so well-developed through the anecdotes of King John's abuse, is present in two significant places early on. The first is Marshal's introduction to royal service, when he is severely wounded during an ambush in which his uncle, earl Patrick of Salisbury, was killed trying to protect Queen Eleanor. Marshal's brave comportment and the trials that he underwent as a hostage reached the ear of the queen, who paid his ransom and supplied him with horses, money, and arms. ${ }^{178}$ Subsequently King Henry II placed Marshal in his son Henry's household, and the two became close. The History says that the Young King "very much bore in mind the Marshal's honour and well- / being, / since he well knew that the Marshal bore in mind his own; / so long had he tried and tested him." 179 But the History says that jealousy of Marshal's close relationship with the Young King festered until a plot was hatched to destroy it. The

\footnotetext{
${ }^{178}$ Ibid., 97.

${ }^{179}$ Ibid., 147.
} 
conspirators were angered that Marshal eclipsed them all in glory, including Henry the Young King, especially by use of his battle cry of "God is with the Marshal." Worse, the History claims that the conspirators brought a false claim of adultery with Henry's wife against Marshal. ${ }^{180}$ The conspirators were successful, according to the History, and Marshal withdrew from Henry's court. David Crouch has argued that the problem of the battle cry was probably the real issue, because adultery "is such a totally absurd fabrication that it has to have been invented by the biographer to make the charge of lèse majesté against the Marshal appear totally unsustainable. A man accused of adultery with a queen would never have survived the charge if it had been in any way sustainable." ${ }^{181}$ This assessment is much more in keeping with the tone of the rest of the History as well, which as has been seen, represents Marshal as a humble royal servant.

In similar fashion to later scenes involving King John, the Young King's advisers recommended unanimously that the king recall Marshal after the conspiracy was brought to light because Marshal "has so often / given you such excellent advice, / and will be capable of giving you better now / than all your advisers" (regarding Henry's conflict with his father). ${ }^{182}$ After Henry's death, Henry II “retained him in his household / and appointed him his chief advisor." ${ }^{183}$ Likewise, after the elder Henry’s death King Richard placed great faith in Marshal, ordering him to go to England "and take charge of my land

\footnotetext{
${ }^{180}$ For the conspirators' claims and motivation, see ibid., 263-267.

${ }^{181}$ Crouch, "Biography as Propaganda," 509.

${ }^{182}$ History of William Marshal, 1:333.

${ }^{183}$ Ibid., 373.
} 
/ and all my other interests." 184 These types of details set the stage for the main drama of King John's reign and represent Marshal as fundamentally consistent throughout his life.

One significant exception occurs during the scene which explains Marshal's decision to support John's kingship after Richard's death. The decision is made in consultation with Hubert Walter, the archbishop of Canterbury, who initially suggests that Arthur of Brittany (John's nephew) should be made king. Marshal's advocacy for John is the one instance in the History that records him making a major decision without outside consensus, and the archbishop warns him that he will regret his decision, a warning that likely reflects young Marshal's view. However, the History indicates that his decision was made in accordance with what he felt to be just for the members of the Plantagenet family, namely that John had a stronger claim to the throne. ${ }^{185}$

Except for the initial decision to support John's kingship, the History is filled with examples of support for Marshal. In the case of another of Marshal's problematic decisions, this time to pay homage to King Philip for his Norman lands, the biography argues that Marshal had John's permission to do so, and that his initial course of action was decided in consultation with Robert, earl of Leicester. Once the deed was done, however, John denied ever having given his consent and urged his barons to pass judgment on Marshal. The silence of the barons indicates their unwillingness to do any such thing, and John angrily declares, "God's Teeth! I can well see that none / of my barons is with me in this matter; / that is very plain to see." Turning to his young knights, John's wishes are foiled once more. In response, John demands the young Marshal as a

\footnotetext{
${ }^{185}$ History of William Marshal, 2:95-97.
} 
hostage, and the father acquiesces, "being as he was a man who would have nothing to do / with evil-doing or ever thought of such."186

A scene in which John attempts to try Marshal for harboring his enemy, William de Briouze, has a similar outcome. Marshal asserts that at the time he gave shelter to Briouze, he was unaware that he was in conflict with John. Much to John's chagrin, "there was not a baron who came forward," and John once again resorted to taking hostages. Marshal, ever desiring to demonstrate his loyalty and humble servitude, offered to provide more hostages than demanded by the king. John's councilors are reported as having advised the king en masse that "a man who is prepared to make such an offer / has no intention of doing wrong; / he offers more than you ask / and does all you command / ... / your great anger towards him is really displaced."

After this period of tension between the king and Marshal, John is persuaded to call on Marshal in a time of military need. Once again, the king's councilors advocate for Marshal. Speaking for all, his anonymous champion informs the king, "I can tell you / that you haven't here with you the worthiest man / in the whole of your kingdom, / and I really advise you to send for him: / I mean William the Marshal, / who is so worthy and loyal, / so esteemed and loved, / and so feared, / that it is a good thing to take his advice / ... / it would be a good thing for you to send for him; / we all stand by this plan of action.” John agreed, released Marshal's sons as an act of goodwill, and summoned Marshal, who responded speedily and "did not stop to inquire what it was all about, / or to ponder on the King's cruel conduct towards him, / for he was ever a man to espouse

\footnotetext{
${ }^{186}$ Ibid., 145, 161-165.

${ }^{187}$ Ibid., 217-219.
} 
the cause of loyalty." ${ }^{188}$ King John's decline and death set the scene for Marshal's climb to the regency and greater advocacy, this time offered by the king himself. Marshal was nearby when John died, for, "whatever the king had done to him, / he never abandoned him for anyone." The king recognized this on his deathbed, and, after begging the other barons to plead with Marshal that he should forgive him, entreated them "to see that he takes charge of my son / and always keeps him under his care, / for my son will never govern these lands of mine with / the help of anyone but the Marshal." ${ }^{\prime 89}$ After the king's endorsement of Marshal and his death follows a lengthy section during which the crucial scenes of Marshal's acquisition of power play out. The king's is only the first of many subsequent validations.

In the rush to secure Henry's kingship after his father's death, the History depicts Marshal beset by requests from his fellow barons to take over more and more of the burdens of leadership. But the second validation of Marshal's new power comes from the child Henry himself, who informs Marshal that "I give myself to God and yourself, / so that in God's name you may take charge of me." Next, the more powerful barons present agreed that Marshal should have the honor of knighting the child, for, "even if there were a thousand of us put together, / there would be nobody of such importance" as Marshal.

Finally, they addressed Marshal about the issue of governance:

The high-ranking men present, following a joint consultation, approached the Marshal and said: "My lord, listen to the words we wish to say to you: you have dubbed your lord a knight, to your great honour,

\footnotetext{
${ }^{188}$ Ibid., 227, 231.

${ }^{189}$ Ibid., 261.
} 
for through you he wears the crown.

The thrust of our deliberations, and we believe we are right, is that we all entreat you to take the King under your wing to protect him, for, in good faith, we know that you will do it very well, and more so than any of us, and we have no doubt whatever that, both in times of peace and war, you will govern the land better than anyone else."

Marshal turned them down on account of his advanced age, but suggested that any decisions be left until the absent earl of Chester arrived. ${ }^{190}$ When Chester did arrive, he also urged Marshal to take on the task, but Marshal only acquiesced when the papal legate, Gualo, offered him the remission of all of his sins in return for becoming regent. Marshal then entrusted the young king to the care of Peter des Roches. ${ }^{191}$ The History indicates that Marshal considered his new position to be a great burden. More convincing took place in private before he felt comfortable with his new role. John of Earley offered the opinion that, even if Marshal were to lose England to Louis and be forced to flee with the young king to Ireland, the events would still redound to his honor as a supremely loyal man. This idea put Marshal's mind at ease, and he added that even if all of Henry's men abandoned him, he would stay with him, "even if I had to look for my daily bread." 192

On Marshal's deathbed, conflict cropped up between himself and Peter des Roches over care of the king. The History makes clear, through a speech delivered by Marshal, that Peter's custody of the boy was meant to be a temporary arrangement.

\footnotetext{
${ }^{190}$ For Henry's words, see ibid., 265; for the knighting, see pg. 267; and for the request that Marshal take over governance of the kingdom and his refusal, see pg. 271.

${ }^{191}$ See ibid., 279, 283.

${ }^{192}$ Ibid., 287.
} 
Marshal announced that it had become time for the barons to elect the next guardian of the king and the realm, when Peter interjected with his claim to custody of the king, and (as Nicholas Vincent has aptly observed) the regency. Marshal responded:

'My lord bishop, what you say is wrong, and you really ought to hold your tongue.

You were there when it was all arranged.

It is not very long ago

that you begged me with tears in your eyes, you and the worthy earl of Chester, to be regent and governor

of the King and the realm together;

I think you have become forgetful.

The legate himself took much trouble over the matter and begged and entreated me so much that I accepted in the name of the legate and all of you to take charge of the King and the realm.

My taking charge of the King

was heard about and witnessed by many.

And I can also assure you of this, that I handed the King over to you

for the simple reason that he could not yet travel;

that is why I handed him to you to look after.' 193

Instead of Peter, Marshal and his advisors decided to place the king in the hands of the legate (now Pandulph), for, Marshal observed, "if I entrusted him to one party, / I can tell you, and you must have no doubt on the matter, / that another party would be jealous.", 194

Young Marshal was instructed to hand the king over to the legate in the presence of the barons, but during the transfer Peter seized the king by the head, only to incur the legate's wrath as well as the young Marshal's. Peter's response is not recorded, but Marshal returned to his parents and reported that Peter "had behaved in an insolent manner." 195

\footnotetext{
193 Ibid., 403. For Vincent's interpretation, see Peter des Roches, 180.

${ }^{194}$ History of William Marshal, 2:405.

195 Ibid., 407-409.
} 
The inclusion of the anecdotes concerning Peter may have been important for two reasons: they provided yet another opportunity for the History to stress the unanimity of support given to the Marshal (or at least make a case for its unanimity), and they also undermine Peter's authority while representing him as a member of a faction opposed to the will of Marshal and the legate, a stance which becomes increasingly more relevant after the elder Marshal's death and into the mid-1220s. Vincent has noted that this story about Peter's behavior is unique to the History and does not reflect any immediate and historical change in his status. The king was handed over into the care of the legate, but Peter was the legate's host while he was in England, and so both the king and the legate were integrated into Peter's household. ${ }^{196}$ In acknowledgment of the prominent positions held by Pandulph, Peter, and Hubert de Burgh, Carpenter has explained that "the government was taking on the appearance of a triumvirate" immediately following the elder Marshal's death. ${ }^{197}$ But Peter's influence began to decline in proportion to the growing influence of Hubert de Burgh, whose royal castle policy was orchestrated with Pandulph's assistance. Hubert's alliance with Marshal was arranged only when Peter had left England on pilgrimage. ${ }^{198}$ Furthermore, Crouch has observed that Ranulf of Chester attempted to have himself placed jointly with Marshal in the regency, but the legate and the pope did not agree. ${ }^{199}$ This may explain Marshal's express mention of Chester alongside Peter des Roches. Regardless of Peter's actual status, discrediting his claim to custody of the king and role in the regency at the time of the elder Marshal's death was a

\footnotetext{
196 See Vincent, Peter des Roches, 181-182.

${ }^{197}$ Carpenter, The Minority of Henry III, 104.

198 Ibid., 239.

${ }^{199}$ See Crouch, William Marshal, 126, n. 56.
} 
direct response to Peter's significant place in the 1220 s and an attack on his right to hold that place. The scenes involving Peter likely reveal young Marshal's answer to the bishop's role in delaying his marriage and opposing his ally, Hubert de Burgh. It is Peter, not the elder Marshal and his son, whose influence with the king is suspect.

Peter's objections and the litany of examples of advice and support given to Marshal forcefully represent the man as a leader who respected and represented the will of the barons at the same time that he tirelessly served his king, whether the sovereign happened to be popular or not. This portrait of Marshal was crafted to appeal to as wide an audience as possible. The barons, whether loyal or not, could find a representative in Marshal, and the royal house could find a champion. Crucially for the young Marshal, the History effectively portrays his father as a humble and faithful subject, deflecting any charge that he had been an over-mighty subject, which both the king and his policymakers and the barons would have found distasteful during the 1220s. The History simultaneously removes the memory of any threat posed by Marshal and celebrates his elevation to the leadership of the country. By extension, the success of the father advocates for the son.

The acknowledgement of the beginning of the First Barons' War in the History is equally evenhanded. It is at this point in the narrative when the influence of the young Marshal on the construction of the biography begins to become most blatant. His interests have been served all along, but now specific concerns that were entirely his own are pushed to the forefront. The character of his father continues to be developed in the same vein, but incongruous interjections, never explicitly explained, crop up in the narrative. 
John the poet adopts a decidedly evenhanded approach to the war which can only be a reflection of his patron's past involvement in the rebellion. He wrote that the war began

the strife and criminal conflict between the King and the barons, which, rightly or wrongly, did not come to an end before his death. Some of those turning traitor had been wronged by the King, but there were others who turned against him without justification, men whom he had wronged in no way; he was assailed from almost every side.

But it is not the time to speak now of the episodes and what gave rise to them, for there were many deeds done that were not right by both sides, in very truth, so much so that nobody could believe the wrong done by both parties, if he had not heard of it and seen it for himself; everyone strove to aggravate the harm done. ${ }^{200}$

The tone of this passage is very different from the preceding pages of the History. While the war may have been criminal, the poet has claimed that some rebels were indeed justified in waging war against their sovereign. Such a position being upheld by the elder Marshal as depicted within the History up until this point is unimaginable, but it reflects young Marshal's views perfectly and removes the stigma of disloyalty, since the war was a justifiable rebellion.

Immediately following the passage about the First Barons' War the History jolts unexpectedly into a description of the Marshal children. William and his younger brother Richard have already been introduced, namely in their roles as hostages, but the poet launches into an account of the merits of all ten children. William is of course first, and the poet asserts that "I can tell you that in this kingdom, / as I have heard said, there was

\footnotetext{
${ }^{200}$ History of William Marshal, 2:243-245.
} 
nobody / who so dedicated himself to performing noble exploits / ... / and no man can help but acquire a great reputation / and involve himself in a grand undertaking / who has that sort of witness to his character." It is hard to avoid the conclusion that the poet felt the need to say something of William's merits after introducing the sticky issue of the First Barons' War. A description of his siblings naturally followed. ${ }^{201}$

After concluding the passages about the Marshal children and having "proved logically" that "a good tree bears good fruit,"202 the History continues to digress with a description of the young Marshal's first marriage. The details would appear to be a random inclusion without any background knowledge of the young Marshal's life, however they are included because they are relevant to the court case between Marshal and Falkes over the possession of the manor of Luton. Marshal testified during the case that King Richard had given the manor to Baldwin of Béthune, and he had married Baldwin's daughter Alice. The History provides the details of the marriage contract, namely that "the count d'Aumale [Baldwin] / would give him all his land in England / and everywhere else.” Alice was Baldwin's only child, which made the grant of all of his properties possible. The elder Marshal and Baldwin then went to King John "to ask him to give his consent in the matter / and have a charter drafted to that effect. / The King duly gave his consent, / and not one single detail / of the pledges they had made / was omitted from the charter." The History asserts that both the marriage and the contract

\footnotetext{
${ }^{201}$ For William, see ibid., 245. His siblings are described on pgs. 245-249.

${ }^{202}$ Ibid., 249. The Biblical allusion is to Matthew 7: 17.
} 
were approved by many people. Here then is a reiteration of the young Marshal's claim to possession of the manor of Luton against Falkes. ${ }^{203}$

The manor of Luton and the other three properties which Marshal had been obliged by the royal court to cede to Falkes receive one more subtle reference in the History. After King John's death, the History records that four castles were handed over to Louis. The elder Marshal was not privy to the decision to give up the castles in order to gain a truce and did not approve, according to the History. Furthermore, Louis violated the terms of the truce. In the middle of the account of the fate of the castles, the History records that Falkes, "who at that time was doing well for himself, / came before the King in Bristol," with other high-ranking men. ${ }^{204}$ The reference to Falkes in the middle of an account of the dispossession of the English crown of four properties indicates that the poet may have been using this scene to allude to young Marshal's loss of his four manors. Falkes claimed during the case that King John had in fact granted him the manor of Luton, but the History may be implying here that it was Henry III. Although the identity of the king was not argued during the case, it mattered because land grants could not be made in perpetuity by the government of an underage king. ${ }^{205}$ This may be the reason that Falkes readily conceded that he had given the manor back to Marshal, only to have Marshal re-grant it to him. Marshal of course denied that he had given Falkes any of the manors in perpetuity, and claimed that Falkes was violating their agreement, just as Louis broke the agreed-upon truce.

\footnotetext{
${ }^{203}$ Ibid., 249-251. It should also be noted that the property claim is followed by a lament about Alice's early death.

204 Ibid., 289.

205 See Carpenter, The Minority of Henry III, 18.
} 
Returning to the subject of the elder Marshal, the poet cryptically claimed after his account of the marriages of the Marshal children that "I must pass over in silence the war which subsequently / broke out in England / between the King and his barons, / for there were many incidents / which it would not be profitable to relate; / indeed, to do so might result in harm to myself." ${ }^{206}$ Nevertheless, the poet proceeded to offer an account of the war regardless of any perceived danger. Any mention of the young Marshal's involvement with the rebels is conspicuously absent. He drops out of the narrative while his father fights for John, "sorely grieved by the outrages committed / by both sides," 207 only to encounter his son randomly on the road later on. After young Marshal's unexplained appearance, the History depicts him successfully besieging Knepp castle with his father, then leading half of the royalist army to take Winchester castle, along with the earl of Salisbury, and aiding in the battle of Lincoln. ${ }^{208}$ The History also asserts the Marshal claim to Marlborough briefly in the words of young Marshal and to Caerleon at greater length. ${ }^{209}$ The last sections of the History ensure that young Marshal is closely associated with his father, both militarily and as a key supporting figure during his father's decline and death.

As the History itself indicates, and as David Crouch has discussed, the work has a substantial defensive aspect. Beyond any specific item of contention, the History is broadly concerned with demonstrating and explaining the power of the Marshal family as represented by the first earl of Pembroke, and the second earl by extension. When it is

\footnotetext{
${ }^{206}$ History of William Marshal, 2:253.

${ }^{207}$ Ibid., 255.

${ }^{208}$ See ibid., 297; and pgs. 335-353.

${ }^{209}$ For Marlborough, see ibid., 303; and for Caerleon, see pgs. 391-397. Also see Crouch's discussion of Caerleon in "Biography as Propaganda," 511.
} 
placed within the context of the 1220s and young Marshal's political situation at the time, the contention surrounding Marshal's marriage to the king's sister becomes the most probable catalyst for the commissioning of such a work. The marriage placed young Marshal in the center of debate and his bid for an unprecedented gain in social status opened him up to attack from individuals who were likely opposed to this contravention of tradition and, more urgently, to the alliance between Hubert de Burgh and Marshal. The controversy explains the emphasis that the History places on the support given to the elder Marshal both by his royal patrons and his fellow barons, as well as his loyalty. Those most likely attacking young Marshal and his proposed marriage were headed by royalists like Peter des Roches and Ranulf of Chester, both of whom the History is concerned to demonstrate supported Marshal's regency and acquisition of power.

However, viewing the History as a defense caters to the subtle bias that criticisms of Marshal were overwhelming, or even accurate. It is true that young Marshal's marriage arrangements were successfully delayed for a few years, until 1224, but this does not testify to the status of the elder Marshal's reputation more generally in the 1220s, simply to the entangled nature of the politics involved. The interpretation of some issues that David Crouch has pointed to as major points of contention and concern, including Marshal's homage to King Philip and the need to separate Marshal from King John, cannot be taken for granted. Young Marshal's influence on the work is too pronounced, and his budding alliance with the government was too important, to believe that the History attempted to disguise the elder Marshal's relationship with King John. Rather, the work was commissioned by a man who had no love for the king and who 
thought that his father had been a victim of the king at times. While the History is a perfect illustration of Crouch's assertion that King John was despised, using a work sponsored by someone who opposed the king to argue that the elder Marshal's reputation was degraded by his closeness to the king is problematic. As has been seen, the History simultaneously depicts Marshal's strained relationship with the king, celebrates his loyalty to him, and shows the king in a position of advocacy for Marshal. Young Marshal's royalist alliance casts doubt on the theory that his father had to be defended for that reason, especially since his likely opponents were also led by royalists. A political purpose, however, may also be served by a celebration, which is a legitimate perspective in the case of the History. The young Marshal and his father had their share of supporters, and the son was best served by a positive assertion, and affirmation, of the qualities that had made his father so successful in royal service and ultimately led to his acceptance as regent. The History was certainly not a straightforward biography of a loyal royalist, and its assertions can in fact reveal more about the complex relationship between remembrance, commemoration, and politics that shaped the work. 


\section{Conclusion}

For over the past 100 years, since Paul Meyer made the History widely available to scholars, historians have been intrigued by the document's value as a source and the window that it opened into the life of the first earl of Pembroke. Historians have by and large utilized the History to construct their own histories of William Marshal, writing biographies from information contained within a text itself heralded recently as the first biographical work in any European vernacular. All of these historians have focused their work on the titular subject of the History. Marshal's most recent biographer, David Crouch, has dedicated the most critical thought to the function of the document, but in a manner that is still consistently focused on its protagonist. His ideas have centered on the concept of the History as a posthumous defense of Marshal's reputation against unknown detractors. Marshal was, in his view, suspected of disloyalty to the crown for multiple reasons, the most damning of which was the homage he paid to King Philip Augustus in order to retain his lands in Normandy, and his closeness to King John was scorned. The only sources that Crouch cites to support this argument are the chronicle of Matthew Paris and the Norman cartulary of King Philip.

Reputation is a difficult concept and an even more difficult thing to reconstruct, and Crouch's argument for a posthumous defense is left underdeveloped. The meaning and implications of any historically negative views of Marshal are left unaddressed; the identities of those who may have harbored such views are hidden within generalities. When using the History solely to reconstruct some image of Marshal's life, it is not necessary to address these concerns, because they pertain to the decade following his 
death. However, the study of historiography contemporary to the History has indicated the critical importance of understanding the political and social functions of medieval histories. The functions of these texts do not conform to modern conceptions of genre or historical writing. Labels like biography obscure the features and purposes of works like the History and encourage their anachronistic and almost sole use as sources of facts and data about their subjects. The broader study of medieval historiography encourages an approach to texts that espouses the necessity of examining the circumstances surrounding the production of a particular document.

Although no study of the second earl of Pembroke has been undertaken by historians, surviving and accessible letters and court records, combined with modern studies of the early years of the reign of Henry III, provide enough information to reconstruct his political career, and especially his relationship with the crown. The available historical record indicates that he partook of the same political and property struggles that afflicted both the king and baronage in the aftermath of the First Barons' War. But unlike his peers, the crown, directed by policymaker Hubert de Burgh, chose to pursue an alliance with Marshal the nature of which was unprecedented within England. Marshal's marriage into the royal family provoked backlash and resistance, and years passed before the match was made a reality. Tension surrounding the marriage stemmed from the crown's unparalleled choice to forgo a traditional foreign alliance, and, during a period when powerful subjects like Hubert de Burgh and Falkes de Bréauté were viewed with suspicion, the choice to elevate one subject above all others. The History - the only 
work of baronial history produced during the time-was forged by, and grew out of, these concerns.

The concept of a posthumous defense of the first earl must be understood in reference to the circumstances during the 1220 s and the complex loyalties that the second earl navigated during his life. In response to Marshal's marriage alliance, the group with the most compelling reasons to defame the elder Marshal was that led by Bishop Peter des Roches. The bishop and his adherents were not party to the growing alliance between young Marshal and Hubert de Burgh, and they despised the influence wielded by the justiciar. In particular, his policy of royal castle resumption, enforced mainly to the detriment of those individuals not among his allies, was detested. The alliance with Marshal, which stipulated the grant of a daughter of King John in return for two castles, was an act favoring a single baron. Marshal became the figurehead of the justiciar's policy, reinforcing the unacceptable power of Hubert de Burgh at the same time that he became a figure of controversy himself due to his marriage. Given the senior Marshal's position as regent and his long service to the royal house, charges of disloyalty and abuse of power would have served as effective means of discrediting not only him but his son, who owed everything to his father. The History is obsessed with loyalty and seizes every opportunity to depict support for Marshal in all of his actions and decisions. It is clear that the History was employed to address concerns surrounding the elder Marshal's loyalty and power and celebrate the Marshal family's connection to the royal house, but these concerns only become meaningful when understood within the context of the second earl's circumstances. By charging the first earl with excessive power and 
disloyalty, Peter des Roches and his allies were challenging his son by drawing parallels between the two Marshals.

In viewing the History as a defense, it must now be asserted that the work was just as much if not more a defense of the second earl as it was of the first earl. Nevertheless, the History is a complicated document and all of its component parts, including its defensive elements, must be interpreted with caution. What has been described as an attempt to separate Marshal senior from King John and represent him in opposition to the sovereign must instead be viewed from the perspective of young Marshal, who saw John as an abusive king. Overall the History dedicates a much greater amount of space to King John's persecution of Marshal than to a defense of Marshal's specific actions, doing more to reinforce Marshal's loyalty than explain his reasoning. Young Marshal sought to assert his father's loyalty while simultaneously representing King John unfavorably. Indeed, John's persecutions of Marshal only enhance the quality of Marshal's loyalty and serve as a warning that the over-mighty, as represented by John, fall, while the humble and loyal are rewarded. Other aspects of the History, including the poet's evenhanded approach to the First Barons' War and the time dedicated to describing the arrangement of young Marshal's first marriage, also point to the work's role as a depository of contemporary concerns.

Ultimately, the History was a work of family history that arose out of the conflicts of the second earl of Pembroke's situation in the 1220s and was a response to the resistance to his marriage alliance with the royal house. Placing the History within its proper context enables the document to become a source to study the leading half of the 
decade following the first earl of Pembroke's death, and not just a source of information about Marshal himself. Areas of study could include baronial loyalties and conflicting loyalties within families, or the changing status of the baronage and attitudes towards powerful subjects. Regardless of the topic of choice, the value of the History as a historical source is greatly expanded when stripped of the label of biography and the singular focus that such a label implies. 


\section{Works Cited}

Primary Sources

Calendar of Entries in the Papal Registers Relating to Great Britain and Ireland: Papal Letters, A.D. 1198-1304, edited by William Henry Bliss. Vol. 1. London: H. M. S. O., 1893.

Cartulaire Normand de Philippe-Auguste, Louis VIII, Saint-Louis et Philippe-le-Hardi, edited by Léopold Delisle. 1882. Reprint, Genève: Mégariotis Reprints, 1978.

Curia Regis Rolls, edited by C. T. Flower. Vol. 8. London: H. M. Stationary Office, 1938.

Curia Regis Rolls, edited by C. T. Flower. Vol. 9. London: H. M. Stationary Office, 1952.

Diplomatic Documents Preserved in the Public Record Office, edited by Pierre Chaplais. Vol. 1. London: H. M. Stationary Office, 1964.

Geoffrey of Monmouth. The History of the Kings of Britain, trans. Lewis Thorpe. London: Penguin Books, 1966.

History of William Marshal, edited by A.J. Holden. London: Anglo-Norman Text Society, 2002.

L'Histoire de Guillaume le Maréchal, edited by Paul Meyer. Paris: Librairie Renouard, 1901.

Paris, Matthew. English History from the Year 1235 to 1273, trans. J. A. Giles. New York: AMS Press, 1968.

Pope Honorius III to the Archbishop of Canterbury and the Bishop of Salisbury. June 16, 1222 (16 kalends July). Registers of Pope Honorius III. Vol. 11. Fol. 258. Microfilm, Institute of Historical Research, London.

Roger of Wendover. Roger of Wendover's Flowers of History, Comprising the History of England from the Descent of the Saxons to A.D. 1235, trans. J. A. Giles. London: Henry G. Bohn, 1849.

Royal and Other Historical Letters Illustrative of the Reign of Henry III, edited by Walter Waddington Shirley. London: Longman, Green, Longman, and Roberts, 1862. 
Suger. The Deeds of Louis the Fat, trans. Richard Cusimano and John Moorhead. Washington, D.C.: Catholic University of America Press, 1992.

Secondary Sources

Armstrong, Catherine. William Marshal, Earl of Pembroke. Kennesaw, Ga.: Seneschal Press, 2007.

Baldwin, John W. The Government of Philip Augustus: Foundations of French Royal Power in the Middle Ages. Berkeley: University of California Press, 1986.

Barlow, Frank. Thomas Becket. Berkeley: University of California Press, 1986.

Bartlett, Robert. 'Rewriting Saints' Lives: The Case of Gerald of Wales," Speculum 58 (1983): 598-613.

---. Trial by Fire and Water: The Medieval Judicial Ordeal. Oxford:

Clarendon Press, 1986.

Benson, Larry D. "The Tournament in the Romances of Chrétien de Troyes and L'Histoire de Guillaume le Maréchal." In Chivalric Literature: Essays on Relations between Literature and Life in the Later Middle Ages, ed. Larry D. Benson and John Leyerle, 1-24. Kalamazoo: Medieval Institute Publications, 1980.

Blacker, Jean. The Faces of Time: Portrayal of the Past in Old French and Latin Historical Narrative of the Anglo-Norman Regnum. Austin: University of Texas Press, 1994.

Bradbury, Jim. Philip Augustus: King of France, 1180-1223. London: Longman, 1998.

Carpenter, David. “The Fall of Hubert de Burgh,” Journal of British Studies 19 (1980): 117.

---. The Minority of Henry III. Berkeley: University of California Press, 1990.

---. The Reign of Henry III. London: Hambledon Press, 1996.

Clanchy, M. T. From Memory to Written Record: England, 1066-1307. Cambridge, Mass.: Harvard University Press, 1979. 
Crosland, Jessie. William Marshal: The Last Great Feudal Baron. London: Peter Owen, 1962.

Crouch, David. "Biography as Propaganda in 'The History of William Marshal."” In Convaincre et Persuader: communication et propagande aux XII et XIII siècles, ed. Martin Aurell, 503-512. Poitiers: Université de Poitiers, 2007.

---. William Marshal: Knighthood, War and Chivalry, 1147-1219, $2^{\text {nd }}$ ed. London: Longman, 2002.

---. "Writing a Biography in the Thirteenth Century: The Construction and Composition of the 'History of William Marshal."' In Writing Medieval Biography 750-1250: Essays in Honour of Professor Frank Barlow, ed. David Bates, Julia Crick and Sarah Hamilton, 221-235. Woodbridge, Suffolk: Boydell Press, 2006.

Damian-Grint, Peter. The New Historians of the Twelfth-Century Renaissance: Inventing Vernacular Authority. Woodbridge, Suffolk: Boydell Press, 1999.

Douglas, David C. William the Conqueror: The Norman Impact upon England. Berkeley: University of California Press, 1964.

Duby, Georges. William Marshal: The Flower of Chivalry, trans. Richard Howard. New York: Pantheon Books, 1985.

Fleischman, Suzanne. "On the Representation of History and Fiction in the Middle Ages," History and Theory 22 (1983): 278-310.

Gaucher, Elisabeth. La biographie chevaleresque: Typologie d'un genre, XIIIe-XVe siècle. Paris: H. Champion, 1994.

Gransden, Antonia. Historical Writing in England c. 550 to c. 1307. Ithaca, New York: Cornell University Press, 1974.

Heffernan, Thomas J. Sacred Biography: Saints and Their Biographers in the Middle Ages. New York: Oxford University Press, 1988.

Jarman, Thomas Leckie. William Marshal, First Earl of Pembroke and Regent of England (1216-1219). Oxford: B. Blackwell, 1930.

King, Edmund. "The Gesta Stephani." In Writing Medieval Biography, 750-1250: Essays in Honour of Professor Frank Barlow, eds. David Bates, Julia Crick, and Sarah Hamilton, 195-206. Woodbridge, Suffolk: Boydell Press, 2006. 
Legge, M. Dominica. Anglo-Norman Literature and Its Background. Oxford: Clarendon Press, 1963.

Lifshitz, Felice. "Beyond Positivism and Genre: 'Hagiographical' Texts as Historical Narrative," Viator 25 (1994): 95-113.

Mullally, Evelyn. "Did John of Earley Write the Histoire de Guillaume le Maréchal?" In The Court Reconvenes: Courtly Literature Across the Disciplines, ed. Barbara Altmann and Carleton Carroll, 255-264. Cambridge: D. S. Brewer, 2003.

Norgate, Kate. The Minority of Henry III. London: MacMillan, 1912.

Otter, Monika. "Functions of Fiction in Historical Writing." In Writing Medieval History, ed. Nancy Partner, 109-130. London: Hodder Arnold, 2005.

Painter, Sidney. William Marshal: Knight-Errant, Baron, and Regent of England. Baltimore: Johns Hopkins Press, 1933.

Powicke, Maurice. The Thirteenth Century, 1216-1307. Oxford: Oxford University Press, 1962.

Rubenstein, Jay. "Biography and Autobiography in the Middle Ages." In Writing Medieval History, ed. Nancy Partner, 22-41. London: Hodder Arnold, 2005.

Shopkow, Leah. "Dynastic History." In Historiography in the Middle Ages, ed. Deborah Mauskopf Deliyannis, 217-248. Leiden: Brill, 2003.

Spiegel, Gabrielle. Romancing the Past: The Rise of Vernacular Prose Historiography in Thirteenth-Century France. Berkeley: University of California Press, 1993.

---. The Past as Text: The Theory and Practice of Medieval Historiography. Baltimore: Johns Hopkins University Press, 1997.

Stacey, Robert. Politics, Policy, and Finance under Henry III, 1216-1245. Oxford: Clarendon Press, 1987.

Tewars. "Marriages of English Princesses." Notes and Queries: A Medium of Intercommunication for Literary Men, General Readers, Etc. 7 (1871): 203-204.

Turner, Ralph. "William de Forz, Count of Aumale: An Early Thirteenth-Century English Baron." Proceedings of the American Philosophical Society 115 (1971): 221-249.

Tyson, D. B. "Patronage of French Vernacular History Writers in the Twelfth and 
Thirteenth Centuries," Romania 100 (1979): 180-222.

Vincent, Nicholas. Peter des Roches: An Alien in English Politics, 1205-1238. Cambridge: Cambridge University Press, 1996.

---. "The Strange Case of the Missing Biographies: The Lives of the Plantagenet Kings of England, 1154-1272." In Writing Medieval Biography, 7501250: Essays in Honour of Professor Frank Barlow, ed. David Bates, Julia Crick, and Sarah Hamilton, 237-257. Woodbridge, Suffolk: Boydell Press, 2006.

Warren, W. L. King John. Berkeley: University of California Press, 1978.

Waugh, Scott L. "Marriage, Class, and Royal Lordship in England under Henry III," Viator 16 (1985): 181-207. 